This item was submitted to Loughborough's Research Repository by the author.

Items in Figshare are protected by copyright, with all rights reserved, unless otherwise indicated.

\title{
Developing and validating a multi-dimensional measure of coopetition
}

PLEASE CITE THE PUBLISHED VERSION

https://doi.org/10.1108/JBIM-07-2018-0217

PUBLISHER

(c) Emerald

VERSION

AM (Accepted Manuscript)

PUBLISHER STATEMENT

This work is made available according to the conditions of the Creative Commons Attribution-NonCommercialNoDerivatives 4.0 International (CC BY-NC-ND 4.0) licence. Full details of this licence are available at: https://creativecommons.org/licenses/by-nc-nd/4.0/

\section{LICENCE}

CC BY-NC-ND 4.0

\section{REPOSITORY RECORD}

Crick, Jim, and David Crick. 2019. "Developing and Validating a Multi-dimensional Measure of Coopetition". figshare. https://hdl.handle.net/2134/37486. 


\title{
DEVELOPING AND VALIDATING A MULTI-DIMENSIONAL MEASURE OF COOPETITION
}

\begin{abstract}
Purpose - Coopetition, namely, the interplay between cooperation and competition has received a good deal of interest in the business-to-business marketing literature. Academics have operationalised the coopetition construct and have employed these measures to test the antecedents and consequences of firms collaborating with their competitors. However, business-to-business marketing scholars have not developed and validated an agreed operationalisation that reflects the dimensionality of the coopetition construct. Thus, the purpose of this study is to develop and validate a multidimensional measure of coopetition for marketing scholars to use in future research.
\end{abstract}

Design/methodology/approach - To utilise a highly-cooperative and highlycompetitive empirical context, sporting organisations in New Zealand were sampled, as the key informants within these entities engaged in different forms of coopetition. Checks were made to ensure that the sampled entities produced generalisable results. That is, it is anticipated that the results apply to other industries with firms engaging in similar business-to-business behaviours. Various sources of qualitative and quantitative data were acquired to develop and validate a multi-dimensional measure of coopetition (the COOP scale), which passed all major assessments of reliability and validity (including common method variance).

Findings - The results indicated that coopetition is a multi-dimensional construct, comprised of three distinct dimensions. First, local-level coopetition is collaboration among competing entities within a close geographic proximity. Second, national-level coopetition is cooperation with rivals within the same country, but across different geographic regions. Third, organisation-level coopetition is cooperation with competitors across different firms (including with indirect rivals), regardless of their geographic location and product-markets served. Indeed, organisation-level coopetition extends to how companies engage in coopetition in domestic and international capacities, depending on the extent to which they compete in similar product-markets in comparison to industry rivals. Also, multiple indicators were used to measure each facet of the coopetition construct after the scale purification stage.

Originality/value - Prior coopetition-based investigations have predominately been conceptual or qualitative in nature. The scarce number of existing scales have significant problems, such as not appreciating that coopetition is a multi-dimensional variable, as well as using single-indicators. Despite a recent call for research on the multiple-levels of coopetition, there has not been an agreed measure of the construct that accounts for its multi-dimensionality. Hence, this investigation responds to such a call for research through developing and validating the COOP scale. Local-level coopetition, national-level coopetition, and organisation-level coopetition are anticipated to be the main facets of the coopetition construct, which offer several avenues for future research.

Key words - Local-level coopetition, national-level coopetition, organisation-level coopetition, scale development and validation, business-to-business marketing, multidimensional variables.

Classification - Research paper. 


\section{Introduction}

Whether to enter into a coopetition strategy is a fundamental business-to-business marketing decision, in which managers cooperate with their competitors to improve their respective firms' performance in ways that would not be possible if they operated individualistically (Bengtsson and Kock, 1999; Rusko, 2011; Akpinar and Vincze, 2016). More formally, coopetition is defined as "a dynamic and paradoxical relationship, which arises when two companies cooperate in some areas (such as strategic alliances), but simultaneously compete in other areas"1 (Bengtsson and Kock, 2000 , p. 411). Coopetition helps to challenge some of the hyper-competitive assumptions of industrial rivalry that appear in theories, like the resource-based view (see Hunt and Derozier, 2004; Dyer et al., 2018). That is, authors have argued that instead of restricting management teams' resources and capabilities to those within the boundaries of their organisations, they should share assets with their competitors to facilitate serving markets that would be difficult under individualistic business strategies (Geldes et al., 2017; Felzensztein et al., 2018). Consequently, coopetition is likely to improve various company performance outcomes, depending on managers' objectives (Czakon and Czernek, 2016; Ranganathan et al., 2018).

Given the potential performance-enhancing nature of coopetition strategies, it is not surprising that a continuing body of research exists on the topic, although many coopetition studies have been conceptual or qualitative (Gnyawali and Park, 2009; Dahl, 2014; Dahl et al., 2016; Granata et al., 2018; Mathias et al., 2018). More importantly, the investigations that have used coopetition in quantitative research have employed measures with limitations. For instance, Ang (2008, p. 1061) used "the

\footnotetext{
1 Revision took place of this definition in 2014 - as discussed later in this current investigation.
} 
number count of collaboration agreements established by a firm by year" from archival data to measure coopetition. Ang (2008) conceptualised cooperation between competitors (coopetition), but the adopted measure focused on broader collaboration, which potentially extended to relationships with other stakeholders. Ritala (2012, p. 314) measured firms' "coopetition alignment, by dividing the number of a firm's alliances with competitors by its total number of alliances." Ritala's (2012) operationalisation is restricted, since coopetition is a multi-dimensional construct (Gnyawali and Park, 2011; Tidstrom and Rajala, 2016). Bouncken and Kraus (2013) developed a multi-item (uni-dimensional) scale for coopetition, but when reporting on their statistical results, this measure was somewhat limited. Later, these authors (and colleagues) used a similar measure of coopetition and while the items exceeded several reliability and validity checks, they measured coopetition as a uni-dimensional variable $^{2}$ (see Bouncken et al., 2018).

Yet, despite the interest in coopetition strategies, marketing scholars have recommended that research should be conducted towards understanding the multiplelevels and multiple dimensions of the coopetition construct (see Bengtsson and Kock, 2014; Raza-Ullah et al., 2014; Bengtsson and Raza-Ullah, 2016). Research has investigated whether various "proximities" affect coopetition. For example, Geldes et al. (2015) examined an agribusiness cluster in Chile and found that coopetition (or inter-firm cooperation) is affected by cognitive, geographical, institutional, organisational, and social proximities. According to Geldes et al. (2015), cognitive proximity is where competitors share similar knowledge and thought processes,

2 Bouncken and Kraus' (2013) measure of coopetition yielded relatively low factor loadings $(\lambda x)$, as well as scale reliabilities. In Bouncken et al.'s (2018) study, the measure of coopetition was better, as improvement took place in the factor loadings $(\lambda x)$, similar to the scale reliabilities. 
geographic proximity is the physical distance between competing businesses, institutional proximity is the set of rules and laws (written and unwritten) that facilitate the cooperation between competitors, organisational proximity is whether competing companies have collaborative relationships within their markets, and social proximity is the degree of trust underpinning inter-firm cooperative behaviours. Hence, following Geldes et al.'s (2015) findings, coopetition could exist across multiple-levels and is a multi-dimensional variable.

Thus, this evidence suggests that coopetition should be measured in a way that reflects how companies can collaborate with their competitors in several capacities. As a further illustration, Crick and Crick (2016) suggested that the coopetition construct can appear in several forms, depending on the physical distance between rival companies and the extent to which firms are competing in the same markets as their counter-parts that they decide to share resources and capabilities with (linking with Geldes et al., 2015). Crick and Crick (2016) presented a framework, depicting locallevel coopetition, national-level coopetition, and organisation-level coopetition, which were used to appreciate the multi-dimensionality of the coopetition construct. Following these conceptualisations, it is of interest to develop and validate a measure of coopetition that uses these three dimensions. Thus, development takes place to build on their work to validate a multi-dimensional operationalisation (the COOP scale). ${ }^{3}$ Moreover, as noted throughout this current study, this investigation responds to a call for research examining the multiple-levels of the coopetition construct (see Bengtsson and Kock, 2014; Raza-Ullah et al., 2014; Bengtsson and Raza-Ullah, 2016; Dahl et al., 2016; Tidstrom and Rajala, 2016).

\footnotetext{
${ }^{3}$ Various terminology exists in the extant literature to define levels at which activities occur, such as, "micro", "meso", and "macro".
} 
In building on prior research, this current study does not consider how coopetition activities can vary between management teams and functional-level employees (namely, coopetition within companies). Instead, this study investigates the different facets of the coopetition construct across geographic-level and organisation-level proximities (building upon Geldes et al., 2015; Crick and Crick, 2016). This is not to say that that the multiple-levels of coopetition within companies is not an important topic (see Luo, 2005; Luo et al., 2006; Ranganathan et al., 2018). Rather, the variation of coopetition across different geographic-level and organisation-level proximities is an alternative perspective to extending existing knowledge related to coopetition (as an under-researched area). Over the course of this current study, the work of Crick and Crick (2016) is revisited to develop and validate a multi-dimensional measure of coopetition that reflects the variation of the coopetition construct across different proximities.

By measuring coopetition as a uni-dimensional construct (Ang, 2008; Ritala, 2012; Bouncken and Kraus, 2013; Bouncken et al., 2018), scholars have overlooked how coopetition can vary across multiple-levels and proximities (Felzensztein and Deans, 2013; Raza-Ullah et al., 2014; Crick and Crick, 2016). Henceforth, the objective of this investigation is to develop and validate a multi-dimensional measure of coopetition (the COOP scale). That is, so that marketing scholars undertaking research in business-to-business marketing contexts have access to a valid and reliable operationalisation to test the antecedents and consequences of coopetition activities (after pre-testing takes place in their own specific context). Thus, the different facets of the coopetition construct are conceptualised, since to appreciate a construct's dimensionality, a need exists to understand its structure (Cadogan, 2012). The format of this study is as follows. First, the extant theory surrounding coopetition is reviewed. 
Second, the population of interest, data collection, and data analysis techniques used to develop this operationalisation are described (alongside several reliability and validity checks). Third, the empirical results are presented. Fourth, the findings are related to the coopetition literature. Fifth, consideration takes place of some practitioner implications, as well as a series of limitations and avenues for future research before the study's conclusions end the paper.

\section{Theoretical background}

\section{Antecedents and consequences of coopetition activities}

A body of knowledge exists that examines the antecedents and consequences of coopetition activities (Bengtsson and Kock, 2000; Gnyawali and Park, 2009; Gnyawali and Charleton, 2018). Specifically, some organisations have limited resources and capabilities that affects their ability to achieve performance objectives (Crick, 2018a). Yet, by collaborating with their competitors, businesses can access new resources, capabilities, and opportunities that allow them to obtain higher-levels of performance (like sales) than if they operated an individualistic business model (Ritala et al., 2014). That is, coopetition activities can yield different outcomes for management teams, such as improved value creation between competing firms, increasing industry standards, enhancing industry dynamics, and boosting various performance consequences (Gnyawali and Park, 2011; Ritala, 2012; Bengtsson and Johansson, 2014). Nevertheless, coopetition is still a competitive business strategy, involving cooperative and competitive forces (Rusko, 2011; Arslan, 2018), meaning that even in the most collaborative forms of coopetition, there will be a degree of rivalry affecting such companies (Bengtsson and Kock, 2014; Czakon and Czernek, 2016). 
Some authors have examined the antecedents of inter-firm relationships (such as Wang and Yang, 2013). However, fewer studies exist regarding the antecedents of coopetition, relative to the consequences of such activities (Crick, 2019a). The limited body of research focusing on the antecedents of coopetition has considered issues, such as firm-level or industry-level mind-sets surrounding managers believing that collaborating with competitors is a performance-driving competitive business strategy (Gnyawali and Park, 2011; Crick, 2018a; Mathias et al., 2018). This body of literature has uncovered that if companies possess coopetition-oriented corporate cultures (or organisation-wide mind-sets), managers (and functional-level employees) will engage in coopetition-oriented behaviours, like resource and capability-sharing activities (Crick, 2019b). Also, coopetition activities could be facilitated when management teams have access to their competitors' resources and capabilities (Geldes et al., 2015). That said, coopetition is effective when the firms involved have reasons to collaborate with one another (Park et al., 2014). Hence, coopetition activities need to benefit all companies involved (Hannah and Eisenhardt, 2018).

\section{Coopetition in the business-to-business marketing literature}

Coopetition research developed in the business-to-business marketing literature. Specifically, publications such as the Journal of Business \& Industrial Marketing and Industrial Marketing Management contributed to a surge of papers surrounding the interplay between cooperation and competition in the late 1990s through to the present-day (Bengtsson and Kock, 1999, Rusko, 2011; Felzensztein and Deans, 2013; Lundgren-Henriksson and Kock, 2016; Felzensztein et al., 2018). As mentioned earlier, authors have examined both the antecedents and consequences of coopetition (Bengtsson and Kock, 2014; Akpinar and Vincze, 2016; Tidstrom and Rajala, 2016; Crick, 2018a). In 2014, a special issue in Industrial Marketing Management published 
a range of coopetition-based articles, for which themes included ways to manage such collaborative business strategies, as well as the tensions that might exist when two or more rival firms share resources and capabilities (see Dahl, 2014; Jain et al., 2014; Tidstrom, 2014; Yami and Nemeh, 2014). This special issue helped the business-tobusiness marketing community of scholars and practitioners to become more aware of the dynamics that underpin coopetition activities.

In their guest editorial of this special issue, Bengtsson and Kock (2014, p. 180) redefined coopetition as "a paradoxical relationship between two or more actors, regardless of whether they are in horizontal or vertical relationships, simultaneously involved in cooperative and competitive interactions". These authors strengthened their earlier definition, which compared coopetition to strategic alliances (closer to horizontal relationships) and restricted such collaborative business strategies to involving only two rival organisations (see Bengtsson and Kock, 2000). In their guest editorial, Bengtsson and Kock (2014) highlighted that coopetition had become a wellestablished topic in the business-to-business marketing literature, but there are still some under-researched areas. They recommended undertaking future research on issues, like the negative aspects of coopetition (such as inter-firm tensions), how companies can manage their coopetition activities, and conceptualising coopetition as a multi-level construct. The latter point supports the objective of this current investigation. However, instead of just conceptualising coopetition existing across multiple-levels, this paper develops and validates a multi-dimensional measure to respond to this call for research (for others to pre-test in their own research contexts).

In terms of the ways that coopetition activities can be best-managed, Dahl (2014) viewed coopetition as a process, in which the formation of collaborative business strategies take place at the inter-section between the potentially conflicting forces of 
cooperativeness and competitiveness. Dahl (2014) highlighted that the employment of coopetition can be formal and informal, whereby, managers need to be aware of the written and unwritten rules surrounding the interplay between cooperation and competition. Furthermore, coopetition is most likely to improve company performance when the forces of cooperativeness and competitiveness are stable for the rival firms involved. Dahl's (2014) study emphasised that coopetition is still a competitive business strategy, in which cooperativeness is matched against a degree of rivalry (and vice-versa). Hence, it is important that management teams are aware of the extent to which their goodwill and collaboration with their competitors ends and the point that rivalry resumes (Mathias et al., 2018). Other studies have suggested that coopetition can potentially have a quadratic relationship with company performance, meaning that firms need to strike a careful balance between the paradoxical forces of cooperativeness and competitiveness (e.g., Luo et al., 2007; Ang, 2008; Crick, 2019a).

The special issue of Industrial Marketing Management also contained several papers examining the tensions that might exist when two or more competing firms share resources and capabilities (Raza-Ullah et al., 2014; Park et al., 2014; Tidstrom, 2014). For example, Raza-Ullah et al. (2014) examined coopetition as a "yin and yang" relationship, whereby, such activities extend beyond the paradoxical forces of cooperativeness and competitiveness (Bengtsson and Kock, 2000). That is, coopetition "materialises by creating an external boundary (via unifying forces) and internal boundaries (via divergent forces)" (Raza-Ullah et al., 2014, p. 189). Yet, these authors recognised that coopetition is likely to be a context-specific issue, as different industries will have particular degrees of cooperativeness and competitiveness. Furthermore, Raza-Ullah et al. (2014) conceptualised coopetition as a multidimensional construct, as there are different forms of coopetition potentially 
implemented by the respective managers and functional-level employees of organisations. Although managers might exhibit their own perceptions towards coopetition as opposed to functional-level employees, cooperative and competitive forces surround the various dimensions of the coopetition construct (Crick, 2018a).

More recently, in 2016, a special section was published in Industrial Marketing Management, in which such articles focused on new directions of the coopetition literature (see Akpinar and Vincze, 2016; Bengtsson and Raza-Ullah, 2016; Czakon and Czernek, 2016; Lundgren-Henriksson and Kock, 2016). For example, Bengtsson and Raza-Ullah (2016) conducted a systematic review of the coopetition literature, finding that there are three schools-of-thought when business-to-business marketing academics conceptualise the coopetition construct. Specifically, the "activity school" examines "coopetition as a one-to-one direct relationship between firms", whereas, "the actor school views coopetition in a broader network context" (Bengtsson and Raza-Ullah, 2016, p. 23). Moreover, Bengtsson and Raza-Ullah (2016) developed the "blended school" as a way to examine the multiple-levels of coopetition. Bengtsson and Raza-Ullah (2016) focused their conceptualisations towards how coopetition differs between management teams and functional-level employees. This current study examines the multi-dimensionality of the coopetition construct. Linking with an earlier point, to extend the work of Crick and Crick (2016) (among other research), the variation of coopetition across different geographic-level and organisation-level proximities features in this investigation.

Dimensionality of the coopetition construct

Certain studies have conceptualised and/or operationalised coopetition from a limited perspective like using a unidimensional measure (e.g., Ang, 2008; Ritala, 2012; 
Bouncken and Kraus, 2013; Bouncken et al., 2018). Other scholars have suggested that there are multiple dimensions of coopetition (Gnyawali and Park, 2011; Felzensztein et al., 2012). For example, Crick (2018a) highlighted that in the context of the wine sector, coopetition can occur in two capacities, namely, resource and capability-sharing activities between two or more rival firms. Resource-sharing activities involve managers collaborating with their competitors in respect of tangible assets (for joint promotions, equipment, and production facilities), whereas, capabilitysharing activities concern intangible assets, such as knowledge and expertise with competing firms (Crick, 2018a; Granata et al., 2018). As previously alluded to, competing firms typically share resources and capabilities to improve their performance in ways that would not be possible if firms were to operate an individualistic business model (Bengtsson and Johansson, 2014; Ritala et al., 2014; Velu, 2016). No matter how much firms collaborate with their competitors, competitive forces always underpin such behavioural forms of coopetition to varying degrees (Arslan, 2018; Crick, 2019b).

Crick and Crick (2016) focused on how firms can collaborate with their competitors across different geographic-level and organisation-level proximities. Using empirical (qualitative) data from a sporting organisation, they found that coopetition activities can exist at a local-level, national-level, and organisation-level. Crick and Crick (2016) suggested that there is no single-form of coopetition (supplementing Bengtsson and Kock, 2014; Raza-Ullah et al., 2014; Bengtsson and Raza-Ullah, 2016), as managers can share resources and capabilities with their competitors in several capacities. It is appreciated that there are various perspectives that business-to-business marketing scholars can take when conceptualising and operationalising the dimensions of the coopetition construct (Bengtsson and Kock, 2014; Dahl et al., 2016; Tidstrom and 
Rajala, 2016). Yet, Crick and Crick's (2016) study is to some extent consistent with other research and highlights how coopetition varies across such geographic-level and organisation-level proximities (Geldes et al., 2015). As such, instead of examining coopetition as a uni-dimensional construct, a multi-dimensional measure would help business-to-business marketing scholars to conceptualise the construct.

\section{Coopetition and the marketing/entrepreneurship interface}

Crick and Crick (2016) underpinned their qualitative investigation by theory positioned at the marketing/entrepreneurship interface (entrepreneurial marketing). This perspective concerns how organisations, especially smaller entities, engage in proactive, innovative, and risk-taking behaviours and use such processes to create value for their customers (Rocks et al., 2005; Crick and Crick, 2018; Crick et al., 2019). The marketing/entrepreneurship interface links the forces of market orientation and entrepreneurial orientation to assist the owner-managers of businesses to improve their market performance (Matsuno et al., 2002). Coopetition is linked with the entrepreneurial marketing literature, as it involves companies taking bold steps (proactive), creative activities (innovative), and making potentially risky decisions (risktaking), involving the interplay between cooperation and competition, which could yield improvements in organisational performance, like sales (Crick, 2019b). By collaborating with competitors, businesses might be able to strengthen their customer value provision by using rivals' resources and capabilities to be well-equipped to satisfy their customers' wants and needs (Rindfleisch and Moorman, 2003).

\section{Local-level coopetition}

Local-level coopetition is cooperation with competitors within a close geographic proximity. Local-level coopetition is frequently employed by organisations when 
sharing equipment and knowledge with their competitors in the same region of a country (Geldes et al., 2015). For example, according to Crick (2018a), in regional clusters, companies might need to access a certain piece of manufacturing equipment that is needed once a year, but is very expensive to purchase. Crick (2018a) added that by engaging in coopetition at a local-level, organisations can borrow such assets from their competitors at a fraction of the cost and invest their financial capital towards competitive business strategies that fulfil their performance objectives. Furthermore, in regional clusters, local-level coopetition could be effective, as firms have access to their competitors' resources and capabilities, allowing them to borrow tangible and intangible assets at relatively little inconvenience (Felzensztein et al., 2018; Granata et al., 2018). This helps explain why coopetition can enhance performance when businesses have access to their rivals' resources and capabilities (Geldes et al., 2015). Hence, local-level coopetition could be a key dimension of the coopetition construct.

\section{National-level coopetition}

National-level coopetition is cooperation with competitors within the same country, but across different geographic regions; that is, when managers do not restrict themselves to a close geographic proximity (Felzensztein and Deans, 2013). For example, Crick and Crick (2016) mentioned sporting clubs working together across regions, but within the same country. With improved forms of communication between organisations, competitors can share resources and capabilities across larger distances (Gnyawali and Charleton, 2018). National-level coopetition includes resource and capabilitysharing activities, but pertain to when the rival firms involved do not need to be within a close geographic proximity to one another (Geldes et al., 2015). National-level coopetition is likely to surround issues, like joint promotions between firms across regions and information-sharing behaviours, as these activities can be employed 
through improvements in technology and infrastructure, such as managers (and functional-level employees) offering advice to their competitors via the internet (Crick, 2015). Thus, national-level coopetition is anticipated to be a facet of the coopetition construct.

\section{Organisation-level coopetition}

Organisation-level coopetition is cooperation with competitors across different organisations, regardless of their geographic location. Organisation-level coopetition extends to when managers access resources and capabilities from their indirect competitors to help them fulfil their objectives (Crick and Crick, 2016). Virtanen and Kock (2016) noted that the "product-market overlap" affecting two or more rival organisations might influence their coopetition behaviours. These authors highlighted that if companies are producing different goods and/or services to their rivals and are competing in the different markets, coopetition poses as a potentially less risky strategy. However, Virtanen and Kock (2016) argued that if firms have a high "productmarket overlap" with their competitors, managers might be less inclined to share resources and capabilities with such organisations, as coopetition poses as a potentially higher risk. As such, coopetition might be influenced at an organisationlevel, depending on the extent to which rivalry exists between the firms involved (Geldes et al., 2015). Consequently, organisation-level coopetition is proposed to be a component of the coopetition construct.

Crick and Crick (2016) explored how organisation-level coopetition can exist in domestic and international capacities. In a domestic sense, they highlighted that the instructors of martial arts clubs can collaborate with their counter-parts in rival organisations, such as Karate and Judo. In such examples, organisation-level 
coopetition pertains to cooperative and competitive behaviours within one country, but being exhibited across product-markets (building upon Virtanen and Kock, 2016). In terms of internationally-oriented organisation-level coopetition, Crick and Crick (2016) provided the example of martial arts instructors sharing knowledge with rival clubs in foreign countries (e.g., at global tournaments). Interestingly, in the extant literature, international forms of coopetition have surrounded how the different subsidiaries owned-operated by multinational enterprises simultaneously cooperate and compete (see Luo, 2005). Yet, Crick and Crick's (2016) study, alongside Virtanen and Kock's (2016) investigation, suggested that organisation-level coopetition surrounds how firms (including smaller entities) can collaborate with their competitors, depending on their "product-market overlap" in domestic and international settings. The adopted methodology follows in the next section.

\section{Methodology}

\section{Population of interest}

When studying coopetition, it is crucial to select an empirical context that demonstrates the interplay between cooperation and competition (Raza-Ullah et al., 2014). Prior empirical contexts in coopetition-based studies have included manufacturing and agricultural sectors, alcohol producers, and sporting organisations (Gnyawali and Park, 2011; Benijts et al., 2011; Felzensztein et al., 2012; Granata et al., 2018). As such, providing an appropriate context helps potential generalisability. The empirical context used for this current investigation was the sporting industry, as many entities within this sector manage high-degrees of cooperativeness and competitiveness (Lorgnier and Su, 2014). Specifically, the research team gained access to a group of senior members of the governing body of an International Taekwon-Do Federation 
(ITF) organisation in New Zealand, with 262 instructors and approximately 3,500 members ${ }^{4}$. Martial arts, like Taekwon-Do, have been studied in the coopetition literature, highlighting that due to its highly-cooperative and highly-competitive empirical context, such sporting entities provide rich insights into the multiple dimensions of the coopetition construct (Crick and Crick, 2016). The senior official in this sporting organisation allowed the researchers to access various sources of empirical and archival data.

Taekwon-Do was formed in 1955 after the Korean War (1950-1953) by the late General Choi Hong Hi (IX Degree Black Belt) as hand-to-hand combat for soldiers in the South Korean military (Ahn et al., 2009). Due to the international political differences between the opposing regimes in North Korea and South Korea, TaekwonDo has divided into numerous "break-away" organisations throughout the world (Hong, 2011) and with the particular spelling of "Taekwon-Do". For instance, in 1973, due to the increasing political angst on the Korean Peninsula, the South Korean government established the World Taekwondo Federation (WTF), which is associated with the Olympic Games (Merkel, 2008). Although cooperation exists at multiple-levels, there is a degree of rivalry affecting the sport (Crick and Crick, 2016). With the high-degree of political volatility within Taekwon-Do, instructors are faced with the challenge of recruiting and retaining students (customers) before they change to other codes of the sport (Kim et al., 2009). It follows that cooperative and competitive behaviours simultaneously exist within Taekwon-Do, making it a suitable setting for this current study.

\footnotetext{
${ }^{4}$ While there was a convenience factor in being granted access to an ITF organisation in New Zealand, this empirical context was theoretically appropriate for this study, following the business-to-business marketing literature (Benijts et al., 2011; Lorgnier and Su, 2014; Crick and Crick, 2016).
} 


\section{Generalisability}

The interviews with the senior official of the sporting organisation established that the clubs operate (or are run) as private (growth-oriented) entities, with the objective of making profits. Thus, despite being in one industry, these sporting organisations are somewhat comparable with businesses in other populations; that is, those offering certain goods/services in exchange for financial revenues. Consequently, the results are likely to be generalisable to other profit-oriented firms in the sporting industry, in addition to similar organisations in other sectors. In fact, particular studies have utilised data from sporting entities to contribute to the marketing and wider coopetition literature (see Benijts et al., 2011; Lorgnier and Su, 2014; Wetzel et al., 2018). Additionally, not all industries host companies that are prepared to engage in different forms of coopetition, as competitiveness often outweighs any cooperation (Raza-Ullah et al., 2014). Hence, it is important for researchers to locate a suitable empirical context for studying coopetition, but nonetheless, theory should drive the use of a coopetitionoriented empirical context (Crick, 2018b).

While generalisability is an aim of this current study, it is important for the COOP scale to be transferrable to populations that facilitate the interplay between cooperation and competition rather than empirical contexts where coopetition does not occur. However, the empirical context is merely a sample that originated from one setting used to strengthen the coopetition literature. Indeed, other authors have used empirical data from sporting organisations to contribute to generical theoretical issues. As an illustration, Hodgkinson et al. (2012) examined the deployment of market-oriented behaviours, using empirical data from British sporting organisations. For clarity, the sporting context was designed to contribute to a broader theoretical issue - the limited research pertaining to the multi-dimensionality of the coopetition construct. As 
highlighted later, a future research direction is to apply the COOP scale to non-sporting organisations. Thus, the sporting context followed a similar approach to Hodgkinson et al. (2012) to use sporting organisations to contribute to generic theory.

\section{Key informants}

The key informants were the instructors of the Taekwon-Do clubs in New Zealand. In effect, these were the managers of these organisations and possessed the decisionmaking capabilities to determine what competitive business strategies these sporting clubs engaged in (including coopetition) (following Crick and Crick, 2016). Typically, coopetition has been studied from the perspective of management teams, as these individuals are usually the ones in their companies that decide to share resources and capabilities with their rivals (Bengtsson and Kock, 2000; Gnyawali and Park, 2009; Ritala, 2012; Dahl, 2014; Velu, 2016; Dyer et al., 2018; Hannah and Eisenhardt, 2018). As described later, use was made of an informant quality scale to check whether respondents were qualified to participate in this study (as per Hultman et al., 2009). This scale suggested that the informants were well-suited to this investigation's themes. Additionally, use was made of the informant quality scale to evaluate evidence of face validity and to test for common method variance under the marker variable technique (as discussed in later sections of this study).

\section{Data collection techniques}

The following data collection techniques were employed in this investigation. First, a preliminary qualitative investigation (guided by Katsikeas et al., 2006) was undertaken, involving semi-structured interviews with instructors operating the sporting clubs $(\mathrm{n}=$ 25) to understand the management of coopetition, focusing on local-level coopetition, national-level coopetition, and organisation-level coopetition. These semi-structured 
interviews were used to explore the dimensionality of the coopetition construct, for which some illustrative quotes are presented in later sections of this study to evidence support for the work of Crick and Crick (2016). Second, a preliminary quantitative study was conducted (through an electronic survey, using Qualtrics) with similar individuals to the previous stage $(n=59)$, where questions were asked about the magnitude of collaboration with competitors to establish the extent to which the empirical context was highly-cooperative and highly-competitive ${ }^{5}$. These preliminary studies were used to generate numerous items for each of the three anticipated dimensions of coopetition (as presented later). Third, an electronic survey was designed, via Qualtrics, containing questions about the different forms of coopetition. This electronic survey was pre-tested, using semi-structured interviews with members of these sporting organisations (practitioners) $(\mathrm{n}=20)$ and marketing academics who were knowledgeable about the focus of this study $(n=10)$.

Pre-testing the survey involved providing the participants with an opportunity to offer feedback before the main study took place; such comments pertained to issues like its readability and use of appropriate content (building on the recommendations of Reynolds and Diamantopoulos, 1998). Specifically, the 30 pre-testing interviews were utilised to examine the positive and negative aspects of the survey. In terms of the positive issues, the interviewees discussed matters, such as, its aesthetics and structure. Regarding somewhat negative issues, the researchers focused on the items for local-level coopetition, national-level coopetition, and organisation-level coopetition. The feedback revealed that certain items were problematic; for instance,

${ }^{5}$ An electronic survey was used instead of a mail survey, as they have various advantages, like being more interactive for respondents, raw data can be automatically transferred into statistical data analysis packages (e.g., SPSS 23), and it is easier to track survey completions (Schibrowsky et al., 2007). 
being repetitive or using confusing terminology. Hence, the pre-testing stage was a good opportunity to improve the content and cosmetic appeal of the survey before any statistical data were collected. The items generated after the preliminary qualitative and quantitative studies (including item deletion after the pre-testing stage) follow later.

Fourth, once the data from the pre-testing stage were analysed, a pilot study was undertaken with the instructors in the sporting organisations $(n=31)$. Pilot studies allow researchers to run initial statistical analyses, by checking for issues, such as the distributions of scales (following Hunt et al., 1982). Fifth, after the pilot study was completed, the researchers analysed the findings to determine whether there were any problems with the raw data, like skewed measures or unreliable scales (via SPSS 23). The results did not suggest that there were any problems with the survey, for which the researchers proceeded with the core sample of sporting clubs ( $n=120)$. No changes were made to the survey between the pilot study and administering the core study; therefore, the two datasets were merged (using SPSS 23) (following Morgan and Hunt, 1994).

By acquiring a larger sample size, through merging the pilot study data with the data from the core study, the researchers could use advanced (multivariate) statistical techniques to develop and validate the COOP scale ${ }^{6}$. For example, a confirmatory factor analysis could be utilised, due to increasing the number of observations, relative to the number of parameter estimates (Stewart, 1981; Moorman, 1995; Peterson, 2000). When collecting the survey data for the core study, the research team recorded

\footnotetext{
6 The final sample size $(n=151)$ was deemed to be large enough to develop and validate the COOP scale. Indeed, the sample size used in this current study was larger than in certain other research within the business-to-business marketing literature. For example, Keinanen and Kuivalainen (2015) used 82 observations to test a relatively complex conceptual framework.
} 
the early versus late responses. Early responses $(n=64)$ were those recorded after the initial wave, whereas, late responses $(n=56)$ were those recorded after participants had been reminded after one-week had passed (consistent with Blair and Zinkhan, 2006). To assess whether there were any effects from early, vis-à-vis, late response bias, $t$-tests were undertaken, revealing that there were no significant differences between the two sub-samples (Armstrong and Overton, 1977). The final sample involved usable survey responses from 151 sporting clubs (for clarity, 31 from the pilot study and 120 cases from the core study), yielding a $57.63 \%$ response rate. Although 151 cases form a relatively low sample size, since there was a high response rate, the total was enough to achieve the study's research objective (Baruch and Holtom, 2008). Further, the research team was fortunate enough to access rich (multisource) data from an empirical context that was highly-cooperative and highlycompetitive $^{7}$ (Benijts et al., 2011; Lorgnier and Su, 2014; Crick and Crick, 2016).

\section{Measures after the preliminary studies}

After considering the findings from the preliminary qualitative and quantitative phases, item development took place for the three anticipated dimensions of the coopetition construct, namely, fourteen items for local-level coopetition, seventeen items for national-level coopetition, and thirteen items for organisation-level coopetition. During these preliminary phases, the researchers measured each facet using seven-point Likert scales. During the pre-testing stage, seven-point Likert scales were found to be understandable for the respondents and were anticipated to capture a high-degree of

\footnotetext{
${ }^{7}$ Facilitation of the high response rate was via a senior member of the ITF organisation in New Zealand endorsing the study and providing support to the researchers when collecting the various sources of qualitative, quantitative, and archival data. Through such support, the individual Taekwon-Do clubs were encouraged (but not pressured) to engage with the study. As such, the high response rate allowed the research team to collect a reasonable sample size, but the data were unlikely to be biased.
} 
variance (consistent with Churchill Jr., 1995). As per usual scale development and validation procedures, numerous items were deleted from the study (see Kohli et al., 1993; Diamantopoulos and Souchon, 1999; Bottger et al., 2017). That is, after these early measures were pre-tested with a sample of academics $(n=10)$ and practitioners $(n=20)$, some were found to be confusing and repetitive. The research team recorded the frequency and percentage of the pre-testing interviewees that indicated problems with these early measures, as a proportion of 30 interviewees (the sum of 20 practitioners and 10 academics). A decision was made to delete items if at least $50 \%$ of the interviewees had concerns, providing that they could articulate why they did not respond well to a certain indicator. Consequently, after the pre-testing stage, four items remained for each of the three dimensions of the coopetition construct.

\section{Measures before the scale purification stage}

The electronic survey was divided into the following four core sections. First, five questions were asked to better-understand the backgrounds of the respondents and their businesses. Measurement of the time that the respondents had trained and been an instructor in the sporting organisation was respectively via a sliding scale, ranging between: 0 and 65 years. To collect data on the size of the respondents' clubs, two questions were asked (both using a sliding scale, ranging between: 1 and 300 individuals) about the number of instructors and students. Lastly, a dropdown menu was provided to the respondents and was used to operationalise the age of their entities. This dropdown menu listed years, ranging between: 1970 and 2017, whereby, 1970 was the year their sporting organisation (the population of interest) was established. Respondents' choices were subtracted from 2018 (the year of this study) to derive a single-score. These profiling variables were used to test for nomological validity (as discussed later). Such demographic variables were originally-developed 
for this study, but were found to be understandable during the pre-testing stage (with academics and practitioners).

Second, the three proposed dimensions were measured through originally-developed seven-point Likert scales, with four respective items (whereby: 1 = very strongly disagree to $7=$ very strongly agree). Third, five items were listed at the end of the survey to measure the extent to which the respondents were knowledgeable to answer its content, namely, the informant quality variable (adapted from Hultman et al., 2009). These five items were measured on a seven-point Likert scale, ranging from: $1=$ very strongly disagree to $7=$ very strongly agree. Fourth, to check for nomological validity (as explained later), a coopetition-oriented mind-set was conceptualised as an organisation-wide belief system surrounding the importance of cooperating with competitors (Gnyawali and Park, 2011; Crick, 2018a; Mathias et al., 2018). This construct was measured on a seven-point Likert scale, with six originally-developed items (ranging from: $1=$ very strongly disagree to $7=$ very strongly agree). As part of the test for nomological validity, competitive intensity was operationalised on a sevenpoint Likert scale, with three items (whereby: $1=$ very strongly disagree to $7=$ very strongly disagree) (adapted from Jaworski and Kohli, 1993).

\section{Data analysis techniques}

The following data analysis techniques were utilised in this investigation. First, regarding the preliminary qualitative study, the research team used a thematic content analysis, in which they developed some pre-determined themes about local-level coopetition, national-level coopetition, and organisation-level coopetition and sifted through the 25 semi-structured interview transcripts for these factors (consistent with Goulding, 2005). The proportion of interviewees that indicated these themes were 
recorded (through manual coding) to highlight the percentage of the sample that represented each of these issues (consistent with Crick, 2018a). Further, the interview data were analysed using the constant comparison technique to gauge how frequently the themes occurred (as per Suddaby, 2006). Second, concerning the preliminary quantitative study, these measures were developed to gauge the degree of coopetition within the population of interest. This data were analysed through their descriptive statistics and scale frequencies as a basic assessment of this exploratory quantitative information (Churchill Jr., 1995). These data analysis techniques were deemed to be acceptable for the preliminary quantitative study.

Third, during the pre-testing stage, these semi-structured interviews were analysed using emergent themes related to whether there were any problems with the survey. The pre-testing interviews were also analysed via the constant comparison technique (guided by Suddaby, 2006). After the problematic indicators were deleted, there were no major concerns with the survey, with the 10 academics and 20 practitioners suggesting that it was understandable. In other words, the items that were used to measure each facet of the coopetition construct were well-suited to their meaning and were phrased in clear language that did not yield any confusion. Fourth, the pilot study data were inputted into SPSS 23. Afterwards, descriptive statistics were reviewed to determine whether the scales captured a high-degree of variance (Hunt et al., 1982). Next, the researchers examined the Cronbach's alpha coefficients ( $\alpha$ ) for all scales (and the scale reliabilities if items were deleted), which yielded scores greater than 0.70 , indicating reliable measures (Churchill Jr., 1979). More robust measures of scale reliabilities will be discussed in later stages of the study.

Fifth, merging of the data from the pilot study with that of the core study took place, since these two datasets contained identical measures (as per Morgan and Hunt, 
1994). As such, the final sample consisted of 151 usable survey responses. At this point, analysis for issues, such as the distributions of each item, the inter-item correlations $(r)$, and some descriptive statistics to handle the data before any advanced (multivariate) statistical tests was undertaken ${ }^{8}$ (consistent with Kohli et al., 1993). Next, the research team examined the Cronbach alpha coefficients $(\alpha)$ for all scales (and the scale reliabilities if items were deleted) to ensure that before any items were deleted in the purification of the measurement scales, they were reliable. Subsequently, three exploratory factor analysis models were used to examine whether the items for the proposed facets of coopetition loaded onto three distinct factors. These models were run using a varimax rotation with a principal components analysis extraction (Model 1), a varimax rotation with a maximum likelihood extraction (Model 2), and a direct oblimin rotation and a principal axis factoring extraction (Model 3) (Netemeyer et al., 2003; Hayton et al., 2004). In the exploratory factor analysis models, the percentage of variance explained $\left(\mathrm{S}^{2}\right)$ by each factor was recorded (Gerbing and Anderson, 1988). The Kaiser-Meyer-Olkin (KMO) test assessed the sampling adequacy and Barlett's test of sphericity explored whether the observations were suited to the data in the exploratory factor analysis models (Bloch et al., 2003). No items were deleted after the exploratory factor analyses.

A confirmatory factor analysis took place to assess the structure of the empirical data (Bottger et al., 2017). Using LISREL 9.30, the researchers examined the factor loadings $(\lambda x)$, error variances $(\theta \delta)$, and $t$-values of all items to ensure that they were the best indicators to measure the three dimensions of coopetition (Anderson et al.,

\footnotetext{
8 The final sample $(n=151)$ did not contain any missing data, meaning that a missing value analysis (e.g., expectation maximisation) was not required (see Kamakura and Wedel, 2000). The lack of missing data was attributed to the survey being relatively short and formatted in a clear structure (as noted from the pre-testing stage), so that respondents answered all the questions.
} 
1987). Through LISREL 9.30, the model fit indices of the confirmatory factor analysis were analysed to examine the degree to which the empirical data represented the framework that it was intended to measure ${ }^{9}$ (Hair Jr. et al., 2017). After deleting problematic items, based on having low factor loadings $(\lambda x)$, high error variances $(\theta \delta)$, non-significant $t$-values, and issues linked with the modification indices, the model fit indices were acceptable, with all surpassing the minimum benchmarks (Fornell and Larcker, 1981). After the confirmatory factor analysis, measurement of each dimension of coopetition took place using two indicators, an issue acceptable for operationalising psychological constructs (Hayduk and Littvay, 2012). That is, while multiple items are preferred in academic research (including in the marketing domain) (Diamantopoulos et al., 2012), two items are acceptable when capturing the variance of latent variables (trace evidence). Appendix 1 provides an overview of the empirical phases used in this investigation.

\section{Reliability}

Reliability is the degree to which researchers will obtain similar results if they were to repeat their investigations in comparable environments (Hulland et al., 2018). Reliability was addressed through the internal consistency method, in which Cronbach's alpha coefficient ( $\alpha$ ) was used to assess the multi-item scales before and after they were processed through exploratory and confirmatory factor analyses

\footnotetext{
${ }^{9}$ Through LISREL 9.30, the chi-square test statistic $\left(x^{2}\right)$ (should be non-significant), the degrees of freedom (df), the root mean square error of approximation (RMSEA) (should be approximately 0.05 ), the non-normed fit index (NNFI) (should be greater than 0.90), the comparative fit index (CFI) (should be greater than 0.90), the incremental fit index (IFI), and the standardised root mean square residual (SRMR) (should be less than 0.08 ) were recorded. Further, the $x^{2} / d f$ was checked, which should yield a value that is less than 3.00 , alongside the significance of the overall $X^{2}$ test statistic. While other model fit indices can be utilised in confirmatory factor analyses, the ones used within this current study were suitable for evaluating the quality of the measurement model.
} 
(Churchill Jr., 1979). All final operationalisations passed the benchmark of 0.70 , suggesting that the scales were reliable (Anderson et al., 1987). As a more robust check, the composite reliabilities (CRs) of the multi-item scales were analysed after the confirmatory factor analysis. As all CRs were greater than 0.60 , the scales were deemed to be reliable (Bottger et al., 2017).

\section{Validity}

Validity is the extent to which researchers have measured what they intended to measure (John and Reve, 1982). In a general sense, to address validity, the electronic survey was designed to contain measures that reflected the dimensions of the coopetition construct that were well-suited to the extant literature (i.e., Crick and Crick, 2016) and were phrased in a clear and understandable manner. Yet, there are several forms of validity (Laurent, 2000); in this paper, content validity, face validity, convergent validity, discriminant validity, and nomological validity were evaluated (following Peter, 1981; Churchill Jr., 1995; Netemeyer et al., 2003; Hultman et al., 2009).

\section{Content validity}

Content validity refers to the theoretical origin of a scale, in terms of whether an operationalisation captures the variance of the construct that it is designed to measure (Peter, 1981). Content validity was evaluated via developing measurement items that were related to the business-to-business marketing literature (Diamantopoulos and Souchon, 1999). Hence, the research team paid close attention to the work of Crick and Crick (2016) to guide this current paper's conceptualisations and measures.

\section{Face validity}

Face validity is a subjective link between a set of items and the theoretical concept that such items are intended to measure (Rossiter, 2008). Face validity was addressed 
through pre-testing the survey with knowledgeable participants (academics and practitioners), who could comment on its readability and content (Reynolds and Diamantopoulos, 1998). Further, an informant quality scale was utilised to monitor how qualified the respondents were to participate in this investigation (adapted from Hultman et al., 2009).

\section{Convergent validity}

Convergent validity is the extent to which a certain construct is closely-related to theoretically-similar constructs that are being tested within a statistical analysis (Peter, 1981). Convergent validity was assessed through using high factor loadings in the exploratory and confirmatory factor analyses and the latent variables having average variance extracted values (AVEs) that were greater than 0.50 (Gerbing and Anderson, 1988).

\section{Discriminant validity}

Discriminant validity is the degree to which a latent variable is distinct from other latent variables within a certain statistical analysis (Netemeyer et al., 2003). Testing for discriminant validity was via examining the squared phi matrix correlations $(\Phi)$ (obtained from the LISREL 9.30 output file). In this comparison, as the highest squared phi matrix correlation $(\Phi)$ was less than the lowest AVE, there was no evidence of discriminant validity problems (Fornell and Larcker, 1981).

\section{Nomological validity}

A scale has nomological validity if it "behaves as expected, with respect to some other construct to which it is theoretically-related" (Churchill Jr., 1995, p. 538). Nomological validity was tested through an ordinary least squares (OLS) multiple regression analysis, for which the relationships between a coopetition-oriented mind-set and the 
three dimensions of coopetition activities were examined (via SPSS 23). If companies have an organisation-wide mind-set surrounding the importance of cooperating with competitors, managers should engage in behavioural forms of coopetition (local-level, national-level, and organisational-level) (Gnyawali and Park, 2011; Crick, 2018a; Mathias et al., 2018). Each OLS multiple regression model controlled for firm size, firm age, and competitive intensity. Regarding firm size, larger organisations, with a greater volume of resources and capabilities, might be more likely to engage in coopetition, due to possessing increased assets to share with competing firms (Bengtsson and Kock, 1999; Luo et al., 2006; Gnyawali and Charleton, 2018; Crick, 2019b). Firm size was measured by summating the number of members (instructors and students) in the sporting clubs (a new measure). This variable was transformed by a natural logarithm to reduce its variance (Hultman et al., 2009).

Concerning firm age, earlier interviews with senior instructors suggested that more established sporting clubs, with greater links with competitors, might be more likely to collaborate with their competitors. The measure of firm age mirrors the earlier description in this study, but transformation took place via a natural logarithm to reduce its variance (Hultman et al., 2009). Competitive intensity was used as a control, as the degree of competitive rivalry within a market could impact the extent to which companies are prepared to collaborate with their competitors (Ang, 2008; Ritala, 2012; Park et al., 2014; Crick, 2019a). The measure of competitive intensity (see Jaworski and Kohli, 1993) did not differ in the test for nomological validity to what was described earlier. In each OLS multiple regression model, examination took place of the standardised regression coefficients $(\beta)$, as well as their $t$-values (and significances). A coopetition-oriented mind-set was positively and significantly related to the different dimensions of coopetition, with the control paths scarcely contributing to the overall 
model. The model fit summaries were examined to assess the amount of the variance explained in each OLS multiple regression analysis (the adjusted $R^{2}$ values, as well as the $F$-statistics and their significances). Therefore, it is anticipated that nomological validity exists (following Churchill Jr., 1995).

\section{Jack-knife procedure}

Since the COOP scale was a new operationalisation, it was important to check whether the results pertained exclusively to the current sample (or have applications to other empirical contexts). As such, the jack-knife procedure was used; this technique involved holding each individual observation and testing the prediction of that observation using the data from the other data points in the nomological validity test (Crask and Perreault Jr., 1977). Specifically, all OLS multiple regression models were run through examining the results of each analysis by deducting one observation ( $\mathrm{n}-$ 1) each time. That is, the research team utilised the jack-knife procedure 150 times to monitor how a change in the sample $(\Delta n)$ affected the nomological validity test (Fenwick, 1979). Then, the researchers utilised SPSS 23 to calculate the $95 \%$ confidence intervals for the ranges from the OLS multiple regression analyses ${ }^{10}$. The relationships between a coopetition-oriented mind-set and each dimension of the coopetition construct (local-level coopetition, national-level coopetition, and organisation-level coopetition) were positive and significant, providing additional evidence of nomological validity. Consequently, the jack-knife procedure suggested

\footnotetext{
${ }^{10}$ Importantly, when the jack-knife procedure was undertaken, certain results in the OLS multiple regression analyses were sensitive to adjustments to the sample size $(\Delta n)$. For example, $t$-values vary as the number of observations decrease. Thus, the researchers were predominately concerned with the differences between the results from the final sample $(n=151)$ and the $95 \%$ confidence intervals that were calculated from the jack-knife procedure. Nonetheless, the authors would like to express gratitude to Professor Wesley J. Johnston (in his editorial capacity) for suggesting the use of the jack-knife procedure to test for nomological validity.
} 
that the results were valid and reliable, without a need to collect data from new samples to validate such results.

\section{Common method variance}

Common method variance "refers to the shared variance among measured variables that arises when they are assessed using a common factor" (Siemsen et al., 2010, p. 456). Researchers have not agreed upon the best approaches for reducing the risk of common method variance in their results. For instance, Chang et al. (2010) discussed how Harman's single-factor test is a popular assessment of common method variance, but is largely invalid as it can suggest that common method variance is non-existent, when in fact, it might be. Other authors have suggested that to check for common method variance, researchers need to select effective instrumental variables and control for endogeneity bias through a two-stage least squares regression analysis (Antonakis et al. 2010). This current study followed the more widely-cited recommendations of Podsakoff et al. (2003), in which the survey was made as short and interactive as possible to engage the respondents, as well as using a mixture of scale types (e.g., sliding scales, vis-à-vis, dropdown menus). Additionally, all respondents received assurance of complete confidentiality to encourage them to provide truthful answers (see Malhotra et al., 2017).

Using data provided by Qualtrics and inputted into SPSS 23, recording of the amount of time each respondent had taken to complete the survey took place. Respondents appeared to take the time estimated by Qualtrics to answer all questions; hence, the survey received appropriate consideration. Regarding testing for common method variance, the marker variable technique was used (Podsakoff et al., 2003). A construct that was conceptually-unrelated to any other variable within the statistical analysis (the 
informant quality variable) was included within a correlational analysis. Through SPSS 23, a bivariate correlation matrix was produced, examining the relationships between the latent variables, using the final measures. These bivariate Pearson correlation coefficients ( $r$ ) were compared against a partial correlation matrix, accounting for the informant quality item as a control. The differences between the bivariate and partial Pearson correlation coefficients $(r)$ were averaged. As there was a very small difference within the correlational analysis, under the marker variable technique, common method variance is highly-unlikely to have affected the statistical findings (as per Lindell and Whitney, 2001). This study's results follow in the next section.

\section{Results}

\section{Findings from the preliminary qualitative study}

In respect of the interviews involving sporting clubs $(n=25)$, questions were asked about the three anticipated dimensions of the coopetition construct. The interview data were divided into three themes, namely, local-level coopetition (theme 1), nationallevel coopetition (theme 2), and organisation-level coopetition (theme 3). Regarding theme 1, all interviewees and 21 out of the 25 interviewees in particular (84\% of the sample) indicated that coopetition occurs with rival clubs within a close geographic proximity. Some illustrative quotes were:

[...] sure, we cooperate with our rivals. It's typically those in region withheld, as it's easier to borrow things from them (Interviewee 1).

[...] I have great relationships with competing clubs from across this area. They're great folks and we work with them all the time (Interviewee 8).

[...] we're always borrowing equipment from other [rival] clubs. Usually, it's with club name withheld, as they're just down the road to us (Interviewee 13).

[...] I run a small club, which means that I don't have loads of equipment. I'm good mates with a group of the local instructors, so I can borrow stuff when I need to (Interviewee 15). 
[...] if I need help, I can always get it. I'm constantly collaborating with the other clubs in the area (interviewee 22).

Concerning theme 2, all interviewees and 23 out of the 25 interviewees $(92 \%$ of the sample) particularly suggested that coopetition took place with rival clubs across multiple geographic regions in the country. Some example quotes were:

[...] just because an instructor is on the other side of the country, doesn't mean that they don't collaborate [with us] ... I'm always visiting other [rival] clubs (Interviewee $6)$.

[...] I have some great relationships with competing clubs all over New Zealand (Interviewee 10).

[...] l'm happy to give my fellow [rival] instructors a call if they need any advice or my wisdom. All they need to do is ask (Interviewee 19).

[...] the other week, I mailed a load of second-hand equipment to another club in region withheld. They needed it and we could spare it, no problem (Interviewee 22).

[...] regional boundaries mean nothing. I've driven hundreds of kilometres to visit other [rival] clubs. Most are run by some close friends (Interviewee 25).

In terms of theme 3 , all interviewees and 22 out of the 25 interviewees in particular (88\% of the sample) highlighted that coopetition extends to collaborating with competitors with various organisations, like indirect rivals. Importantly, organisationlevel coopetition extends to the "product-market overlap" that the sampled entities shared with their rivals. Consequently, organisation-level coopetition included firms collaborating with such competitors on a domestic and international scale. Some selected quotes from theme 3 included:

[...] just because a club isn't affiliated to our style of Taekwon-Do, doesn't mean that we won't work with them (Interviewee 2).

[...] I've got friends who train in all sorts of martial arts. I will help them just as much as I would with someone in my organisation (Interviewee 7).

[...] my club is relatively large, so l'm always loaning out equipment (Interviewee 17).

[...] my best friends train in the likes of Karate and Judo. I borrow equipment and ask for their advice whenever I need to (Interviewee 20).

[...] there are some great guys training in other sports than Taekwon-Do in my town. I think it would be foolish to not work with them (Interviewee 24). 
These three themes were used to generate a list of items pertaining to the anticipated dimensions of the coopetition construct. Once the final sample for the scale development and validation stage was obtained $(n=151)$, these items were refined during the pre-testing interviews (Table 1). Also, as the qualitative evidence was highly-indicative of coopetition existing at a local-level, national-level, and organisation-level, there was some preliminary support for these three dimensions representing the facets of the coopetition construct. In other words, these components of the COOP scale reflect the main ways that companies can collaborate with their competitors and supplement the existing business-to-business marketing literature.

[Insert Table 1 about here]

\section{Characteristics of the final sample}

The profiling information revealed that there was a good distribution of participants and entities, such as the size and age of the sampled organisations (Table 2).

\section{[Insert Table 2 about here]}

\section{Descriptive statistics of the initial measures}

Once the problematic items were deleted after the pre-testing stage, the initial descriptive statistics of the multiple facets of coopetition were studied before any advanced (multivariate) statistical procedures were undertaken. For the three anticipated dimensions of coopetition, all items had means towards the centre of the measurement scales and relatively large standard deviations (SDs). Moreover, the respondents utilised all scale points, suggesting that the initial measures captured a high-degree of variance. Concerning the items used to measure the informant quality variable, overall, the respondents were knowledgeable and qualified to complete the 
survey. Likewise, as part of the test for nomological validity (as presented later), the items for the coopetition-oriented mind-set and competitive intensity variables had good descriptive statistics (Table 3).

[Insert Table 3 about here]

\section{Scale reliabilities of the initial measures}

The initial scale reliabilities for the different facets of coopetition and the informant quality scale had Cronbach's alpha coefficients $(\alpha)$ that were above the minimum threshold of 0.70 (acceptable values). Specifically, local-level coopetition $(\alpha=0.94)$, national-level coopetition ( $\alpha=0.91$ ), organisation-level coopetition $(\alpha=0.87$ ), and the informant quality scale $(\alpha=0.94)$ were indicative of reliable scales. Examination took place regarding the improvements to the Cronbach's alpha coefficients $(\alpha)$ with item deletion, but this approach did not reveal any problematic indicators. Also, as part of the test for nomological validity (as shown later), the Cronbach alpha coefficients ( $\alpha$ ) for the coopetition-oriented mind-set $(\alpha=0.95)$ and competitive intensity $(\alpha=0.72)$ were satisfactory.

\section{Inter-item correlations of the initial measures}

The items for each facet of coopetition were closely-associated, suggesting that these individual indicators were effective measures of each dimension of the coopetition construct. The inter-item bivariate Pearson correlation coefficients $(r)$ intended to measure the different facets of coopetition were positive and significant, but were not overly-correlated (not exceeding $r=0.58$ ). Further, the five informant quality items were included within the correlational analysis, as a preliminary part of the marker variable technique, suggesting no concerns (not exceeding $r=0.17$ ) (please see Appendix 2). 


\section{Exploratory factor analyses}

The items for the three anticipated dimensions of coopetition were inputted into three exploratory factor analysis models, alongside the informant quality items (Table 4). The results indicated that coopetition is comprised of the three identified distinct facets, with high factor loadings and no cross-factor loadings (under the three extraction and rotation approaches). The informant quality items did not cross-load on to any other factor. The total variance explained $\left(S^{2}\right)$ was $81.06 \%$ in Model 1, $74.59 \%$ in Model 2 , and $75.52 \%$ in Model 3. Lastly, the KMO test of sampling adequacy $(0.80)$ and Bartlett's test of sphericity $\left(X^{2}=2,769.39\right.$; $d f=136$; Sig. $\left.=0.00\right)$ yielded acceptable results. Hence, regardless of the exploratory factor analysis model used, the facets of the coopetition construct were statistically distinct, as shown with their loadings onto individual components.

[Insert Table 4 about here]

\section{Confirmatory factor analysis}

During the confirmatory factor analysis, several model fit indices were used. Before item deletion took place, a weak set of model fit indices was evident. Once certain items were deleted from the statistical analysis, the model fit indices yielded acceptable values (Table 5).

[Insert Table 5 about here]

After deleting these multiple items, each facet of the coopetition construct had more than one indicator, for which the factor loadings $(\lambda x)$, error variances $(\theta \delta)$, and $t$-values for all items were high and significant, suggesting that they were accurate in capturing trace evidence of the different factors (latent variables) (Table 6). 
[Insert Table 6 about here]

Final scale reliabilities

After the scale purification stage, the final scale reliabilities were recorded. Specifically, the Cronbach's alpha coefficients $(\alpha)$, CRs, and AVEs were above the minimum benchmarks, contributing to there being evidence of reliable measures and convergent validity. Moreover, in terms of the discriminant validity test, as the highest squared phi matrix correlation $(\Phi)(0.26)$ was less than the lowest AVE $(0.78)$, discriminant validity is highly-likely to exist (Table 7).

[Insert Table 7 about here]

Tests for nomological validity

To test for nomological validity, the relationships between a coopetition-oriented mindset and the different dimensions of coopetition activities were examined. The Pearson correlation coefficients $(r)$ between the averaged constructs suggested the extent to which the variables were related (Table 8).

[Insert Table 8 about here]

In the three OLS multiple regression models, the relationships between a coopetitionoriented mind-set and local-level coopetition $(\beta=0.72 ; t=11.51$; Sig. $=0.00)$, nationallevel coopetition $(\beta=0.59 ; t=9.20$; Sig. $=0.00)$, and organisation-level coopetition $(\beta$ $=0.44 ; t=5.73 ;$ Sig. $=0.00)$ were indicative of nomological validity existing within the statistical data. Also, an acceptable amount of variance was explained by each OLS multiple regression model (as per the adjusted $\mathrm{R}^{2}$ and $F$-statistics) (as shown in Table 9).

[Insert Table 9 about here] 
Jack-knife procedure

The $95 \%$ confidence intervals for the standardised regression coefficients $(\beta), t$-values, and significances suggested that there is likely to be positive and significant relationships between a coopetition-oriented mind-set and the various dimensions of the coopetition construct (local-level coopetition, national-level coopetition, and organisation-level coopetition). In addition, the $95 \%$ confidence intervals suggested that the model fit summaries were accurate, in terms of the adjusted $\mathrm{R}^{2}$ and F-statistics (Appendix 3). Hence, the jack-knife procedure provided supplementary evidence that the COOP scale was valid and reliable, without a necessity to collect data from new samples.

\section{Common method variance}

The five informant quality items (averaged into a single-score) were used to test for common method variance under the marker variable technique. The marker variable had a reasonable degree of variance, with a mean of 5.81 and a SD of 0.67 , allowing testing for common method variance. Through comparing the differences between the bivariate and partial correlation matrices (with the latter controlling for the informant quality variable), common method variance was unlikely to be a problem within this investigation. That is, with an average difference of $r=0.00$ between the bivariate and partial correlation matrices, there was no evidence of common method variancerelated concerns (Appendix 4). The study's discussion follows in the next section.

\section{Discussion}

A body of knowledge exists regarding coopetition in the business-to-business marketing literature, with it viewed as a strategy used to help managers improve their performance compared to if they operated an individualistic business model 
(Bengtsson and Kock, 1999; Felzensztein et al., 2012; Wang and Yang, 2013; Bengtsson and Johansson, 2014; Czakon and Czernek, 2016; Velu, 2016; Crick, 2019a). That said, most authors who have conducted research on coopetition (including its antecedents and consequences) have employed conceptual or qualitative approaches (see Gnyawali and Park, 2009; Rusko, 2011; Dahl et al., 2016; Gnyawali and Charleton, 2018; Mathias et al., 2018). More importantly, the relatively few studies to use quantitative methods to examine coopetition have employed measures with limitations, like using single-item and uni-dimensional operationalisations (see Ang, 2008; Ritala, 2012; Bouncken and Kraus, 2013; Bouncken et al., 2018). As such, this current study developed and validated a measure of coopetition that reflects its multi-dimensionality. Examination of coopetition was via three-components, namely, local-level coopetition, national-level coopetition, and organisation-level coopetition (following Crick and Crick, 2016). A measure of three facets was developed and validated (the COOP scale) using qualitative and quantitative sources of data.

Local-level coopetition involves firms cooperating with their competitors within a close geographic proximity (linking with Geldes et al., 2015; Felzensztein et al., 2018). National-level coopetition is when businesses collaborate with their rivals within the same country, but across geographic regions (see Felzensztein and Deans, 2013; Crick, 2015). Organisation-level coopetition is when companies work with competing entities across different firms (including with indirect rivals), regardless of their geographic location (following Crick and Crick, 2016). Indeed, organisation-level coopetition extends to companies engaging in cooperative and competitive behaviours on a domestic and international scale, based on their "product-market overlap" with their rivals (Virtanen and Kock, 2016). 
This study was especially important and timely, as recent work has recommended that research should be directed towards understanding how coopetition is a multi-level and multi-dimensional construct (see Bengtsson and Kock, 2014; Raza-Ullah et al., 2014; Crick, 2018a). That is, certain authors have argued that there are various ways that organisations can collaborate with their competitors, but such theory often surrounds how managers, vis-à-vis, functional-level employees might manage the complex and potentially paradoxical relationship concerning the interplay between cooperation and competition (Bengtsson and Kock, 2014; Bengtsson and Raza-Ullah, 2016; Ranganathan et al., 2018). This study responded to the call for research by examining the multiple dimensions of coopetition (see Dahl et al., 2016; Tidstrom and Rajala, 2016), but instead of examining coopetition within companies (see Luo et al., 2006), it focused on how coopetition might vary depending on geographic-level and organisation-level proximities (guided by Crick and Crick, 2016). As such, this current investigation built its assertions on recent research in the business-to-business marketing literature that has examined differences between coopetition activities across various types of proximities (Felzensztein and Deans, 2013; Geldes et al., 2015; Felzensztein et al., 2018).

Results from the development and validation of the COOP scale indicated that coopetition is comprised of three distinct dimensions, each of them measured by more than one indicator. By utilising multiple indicators for the three dimensions of coopetition, this study has created a more robust scale than if single-items were used (see Peter, 1981; Diamantopoulos et al., 2012). Multiple indicators, including those with two items, allow researchers to develop a stronger understanding of the trace evidence of certain latent variables (Hayduk and Littvay, 2012). Further, the results highlighted the importance of conceptualising and operationalising the coopetition 
construct as a multi-dimensional variable. While studies employing uni-dimensional measures have incrementally strengthened the coopetition literature (e.g., Ang, 2008; Ritala, 2012; Bouncken and Kraus, 2013; Bouncken et al., 2018), by not appreciating the entirety of the coopetition construct, earlier research has not considered the fullscope of how organisations can collaborate with their competitors. For example, when testing for evidence of nomological validity, the COOP scale supported the assertions that a coopetition-oriented mind-set drives the different behavioural forms of coopetition to varying degrees (supporting Gnyawali and Park, 2011; Crick, 2018a; Mathias et al., 2018).

The COOP scale is especially important for business-to-business marketing theory, as it highlights that the coopetition construct is a multi-dimensional variable. Scholars should embrace the complexity of the variables that they are attempting to conceptualise and operationalise by appreciating that certain constructs are comprised of more than one facet (Cadogan, 2012). Hence, as prior work has typically examined the coopetition construct through uni-dimensional conceptualisations and operationalisations, an inference exists that such studies have restricted their findings to limited information pertaining to the antecedents and consequences of coopetition activities. By employing the COOP scale, business-to-business marketing scholars can obtain a deeper understanding of the antecedents and consequences of coopetition activities. For instance, through testing the COOP scale, there may be evidence that particular dimensions of the coopetition construct might be more likely to drive company performance (like sales) than others. Indeed, this study's results highlight that Crick and Crick's (2016) conceptualisations of the multiple facets of coopetition reflect the dimensionality of the construct. However, to emphasise an 
earlier point, researchers need to pre-test items in respect of the context of their own study. Some practical implications follow in the next section.

\section{Practical implications}

While the contribution of this study focused towards marketing scholars, it also has associated practical benefits. As noted throughout this study, coopetition activities should assist management teams to improve their performance in ways that they would not be able to achieve if they were to operate individualistically (Bengtsson and Kock, 1999; Rusko, 2011; Ritala, 2012; Bengtsson and Johansson, 2014; Czakon and Czernek, 2016; Ranganathan et al., 2018). Yet, since marketing scholars have employed measures of the coopetition construct with certain restrictions (e.g., Ang, 2008; Ritala, 2012; Bouncken and Kraus, 2013; Bouncken et al., 2018), arguably, limited recommendations can be made to practitioners about the extent to which coopetition activities can be managed, as well as their performance consequences. Through utilising the COOP scale, academics can test the antecedents and consequences of these different forms of coopetition activities to make well-rounded

managerial recommendations about the benefits (and potential drawbacks) of collaborating with competitors with targeting different product-markets. A series of limitations and avenues for future research are described as follows.

\section{Limitations and avenues for future research}

Although this study has developed and validated a multi-dimensional measure of coopetition (namely, the COOP scale), there are certain limitations that can be addressed in future research. First, the final sample for the core study was 151 observations. It is appreciated that it would have been ideal to obtain a larger sample size; however, with a high response rate of $57.63 \%$, the sample size was acceptable 
(Moorman, 1995; Baruch and Holtom, 2008; Keinanen and Kuivalainen, 2015). Additionally, the results indicated that the data were robust, suggesting no problems with such a sample size. In future research, academics should strive for larger sample sizes to ensure that their data is representative of their populations of interest. Second, the empirical context involved a sector that exhibited coopetition activities, namely, sporting clubs (see Benijts et al., 2011; Lorgnier and Su, 2014; Crick and Crick, 2016). In future research, scholars should aim to replicate this study using alternative empirical contexts (namely, industries and countries). Third, despite this study identifying that coopetition is comprised of three distinct dimensions (local-level coopetition, national-level coopetition, and organisation-level coopetition) after item deletion took place in the analysis, only two indicators were used to measure each facet of the variable. While two items can satisfactorily capture trace evidence of certain latent variables (Hayduk and Littvay, 2012), in future research, scholars should attempt to replicate this investigation using additional items for each facet of coopetition (Peter, 1981; Diamantopoulos et al., 2012).

Fourth, it is appreciated that the variable organisation-level coopetition can be conceptualised and operationalised in different ways. That is, the research team were guided by the work of Crick and Crick (2016) and found that organisation-level coopetition surrounds businesses collaborating with their competitors across different firms (including with indirect rivals), regardless of their geographic location. Not only did this viewpoint highlight that organisation-level coopetition is based on companies' "product-market overlap" served by their competitors (following Virtanen and Kock, 2016), but also, it is linked with domestic and international forms of coopetition. Following on, there could be other ways that organisation-level coopetition could be explored, depending on the "product-market overlap" involved in their business 
models. Consequently, in future research, academics have scope to investigate organisation-level coopetition in different capacities. For instance, organisation-level coopetition could vary if firms have differing degrees of internationalisation activity (building upon Virtanen and Kock, 2016). Nevertheless, it is argued that these limitations do not pose serious concerns, but instead facilitate ample scope for future research. This study is concluded in the following section.

\section{Conclusions}

The objective of this investigation was to develop and validate a multi-dimensional measure of coopetition (the COOP scale), so that marketing scholars, undertaking research in business-to-business contexts, have access to a valid and reliable operationalisation to test the antecedents and consequences of coopetition activities. To achieve this research objective, data collection took place utilising sporting clubs in New Zealand (using qualitative and quantitative methods). Such data were analysed using a range of techniques, for which the COOP scale passed all major assessments of reliability and validity (including common method variance). The conclusion is that the coopetition construct is comprised of three facets, namely, local-level coopetition, national-level coopetition, and organisation-level coopetition. These three dimensions were measured using multiple items. In closing, this improved measurement scale has ample scope to extend the coopetition literature in future empirical research within the business-to-business marketing domain. 


\section{References}

Ahn, J.D., Hong, S.D. and Park, Y.K. (2009), "The historical and cultural identity of Taekwondo as a traditional Korean martial art", International Journal of the History of Sport, Vol. 26 No. 11, pp. 1716-1734.

Akpinar, M. and Vincze, Z. (2016), "The dynamics of coopetition: a stakeholder view of the German automotive industry”, Industrial Marketing Management, Vol. 57 No. 1, pp. 53-63.

Anderson, J.C., Gerbing, D.W. and Hunter, J.E. (1987), "On the assessment of unidimensional measurement: internal and external consistency, and overall consistency criteria", Journal of Marketing Research, Vol. 24 No. 4, pp. 432-437.

Ang, S.H. (2008), "Competitive intensity and collaboration: impact on firm growth across technological environments", Strategic Management Journal, Vol. 29 No. 10, pp. 1057-1075.

Antonakis, J., Bendahan, S., Jacquart, P. and Lalive, R. (2010), "On making causal claims: a review and recommendations", Leadership Quarterly, Vol. 21 No. 6, pp. 1086-1120.

Armstrong, J.S. and Overton, T.S. (1977), "Estimating non-response bias in mail surveys", Journal of Marketing Research, Vol. 14 No. 3, pp. 396-402.

Arslan, B. (2018), "The interplay of competitive and cooperative behavior and differential benefits in alliances", Strategic Management Journal, Vol. 39 No. 12, pp. 3222-3246.

Baruch, Y. and Holtom, B.C. (2008), "Survey response rate levels and trends in organizational research", Human Relations, Vol. 61 No. 8, pp. 1139-1160.

Bengtsson, M. and Johansson, M. (2014), "Managing coopetition to create opportunities for small firms", International Small Business Journal, Vol. 32 No. 4, pp. 401-427.

Bengtsson, M. and Kock, S. (1999), "Cooperation and competition in relationships between competitors in business networks", Journal of Business \& Industrial Marketing, Vol. 14 No. 3, pp. 178-194.

Bengtsson, M. and Kock, S. (2000), "Coopetition in business networks: to cooperate and compete simultaneously", Industrial Marketing Management, Vol. 29 No. 5, pp. 411-426.

Bengtsson, M. and Kock, S. (2014), "Coopetition - quo vadis? Past accomplishments and future challenges", Industrial Marketing Management, Vol. 43 No. 2, pp. 180 188.

Bengtsson, M. and Raza-Ullah, T. (2016), "A systematic review of research on coopetition: toward a multi-level understanding", Industrial Marketing Management, Vol. 57 No. 1, pp. 23-39.

Benijts, T., Lagae, W. and Vanclooster, B. (2011), "The influence of sport leagues on the business-to-business marketing of teams: the case of professional road cycling", Journal of Business \& Industrial Marketing, Vol. 26 No. 8, pp. 602-613. 
Blair, E. and Zinkhan, G.M. (2006), "Non-response and generalizability in academic research", Journal of the Academy of Marketing Science, Vol. 34 No. 1, pp. 4-7.

Bloch, P.H., Brunel, F.F. and Arnould, T.J. (2003), "Individual differences in the centrality of visual product aesthetics: concept and measurement", Journal of Consumer Research, Vol. 29 No. 4, pp. 551-565.

Bottger, T., Rudolph, T., Evanschitzky, H. and Pfrang, T. (2017), "Customer inspiration: conceptualization, scale development, and validation”, Journal of Marketing, Vol. 81 No. 6 , pp. $116-131$.

Bouncken, R.B. and Kraus, S. (2013), "Innovation in knowledge-intensive industries: the double-edged sword of coopetition", Journal of Business Research, Vol. 66 No. 10 , pp. $2060-2070$.

Bouncken, R.B., Fredrich, V., Ritala, P. and Kraus, S. (2018), "Coopetition in new product development alliances: advantages and tensions for incremental and radical innovation", British Journal of Management, Vol. 29 No. 3, pp. 391-410.

Cadogan, J.W. (2012), "International marketing, strategic orientations and business success: reflections on the path ahead", International Marketing Review, Vol. 29 No. 4, pp. 340-348.

Chang, S.J., van Witteloostuijn, A. and Eden, L. (2010), "Common method variance in international business research", Journal of International Business Studies, Vol. 41 No. 2, pp. 178-184.

Churchill Jr., G.A. (1979), "A paradigm for developing better measures of marketing constructs", Journal of Marketing Research, Vol. 16 No. 1, pp. 64-73.

Churchill Jr., G.A. (1995), Marketing Research: Methodological Foundations, sixth edition, Dryden Press, Chicago: IL.

Crask, M.R. and Perreault Jr., W.D. (1977), "Validation of discriminant analysis in marketing research", Journal of Marketing Research, Vol. 14 No. 1, pp. 60-68.

Crick, D. and Crick, J.M. (2016), "Coopetition at the sports marketing/entrepreneurship interface: a case study of a Taekwondo organisation", Marketing Intelligence \& Planning, Vol. 34 No. 2, pp. 169-187.

Crick, J.M. (2015), "Bridging the gap between threshold and dynamic capabilities: a qualitative study of the collaboration strategies of New Zealand wineries", unpublished Master of Business Studies thesis in management, Massey University, New Zealand.

Crick, J.M. (2018a), "The facets, antecedents and consequences of coopetition: an entrepreneurial marketing perspective", Qualitative Market Research: An International Journal, Vol. 21 No. 2, pp. 253-272.

Crick, J.M. (2018b), "Studying coopetition in a wine industry context: directions for future research", International Journal of Wine Business Research, Vol. 30 No. 3, pp. 366-371.

Crick, J.M. (2019a), "Moderators affecting the relationship between coopetition and company performance", Journal of Business \& Industrial Marketing, Vol. 34 No. 2, pp. 518-531. 
Crick, J.M. (2019b), "Incorporating coopetition into the entrepreneurial marketing literature: directions for future research", Journal of Research in Marketing and Entrepreneurship (Forthcoming).

Crick, J.M. and Crick, D. (2018), "Angel investors' predictive and control funding criteria: the importance of evolving business models", Journal of Research in Marketing and Entrepreneurship, Vol. 20 No. 1, pp. 34-56.

Crick, J.M., Crick, D. and Chaudhry, S. (2019), "Entrepreneurial marketing decisionmaking in rapidly internationalising and de-internationalising start-up firms", Journal of Business Research (Forthcoming).

Czakon, W. and Czernek, K. (2016), "The role of trust-building mechanisms in entering into network coopetition: the case of tourism networks in Poland", Industrial Marketing Management, Vol. 57 No. 1, pp. 64-74.

Dahl, J. (2014), "Conceptualizing coopetition as a process: an outline of change in cooperative and competitive interactions", Industrial Marketing Management, Vol. 43 No. 2, pp. 272-279.

Dahl, J., Kock, S. and Lundgren-Henriksson, E-L. (2016), "Conceptualizing coopetition strategy as practice: a multi-level interpretative framework", International Studies of Management \& Organization, Vol. 46 Nos. 2/3, pp. 94-109.

Diamantopoulos, A. and Souchon, A.L. (1999), "Measuring export information use: scale development and validation", Journal of Business Research, Vol. 46 No. 1, pp. 1-14.

Diamantopoulos, A., Sarstedt, M., Fuchs, C., Wilczynski, P. and Kaiser, S. (2012), "Guidelines for choosing between multi-item and single-item scales for construct measurement: a predictive validity perspective", Journal of the Academy of Marketing Science, Vol. 40 No. 3, pp. 434-449.

Dyer, J.H., Singh, H. and Hesterly, W.S. (2018), "The relational view revisited: a dynamic perspective on value creation and value capture", Strategic Management Journal, Vol. 39 No. 12, pp. 3140-3162.

Felzensztein, C. and Deans, K.R. (2013), "Marketing practices in wine clusters: insights from Chile", Journal of Business \& Industrial Marketing, Vol. 28 No. 4, pp. 357-367.

Felzensztein, C., Gimmon, E. and Aqueveque, C. (2012), "Clusters or un-clustered industries? Where inter-firm marketing cooperation matters", Journal of Business \& Industrial Marketing, Vol. 27 No. 5, pp. 392-402.

Felzensztein, C., Gimmon, E. and Deans, K.R. (2018), "Coopetition in regional clusters: keep calm and expect unexpected changes", Industrial Marketing Management, Vol. 69 No. 1, pp. 116-124.

Fenwick, I. (1979), "Techniques in market measurement: the jack-knife", Journal of Marketing Research, Vol. 16 No. 3, pp. 410-414.

Fornell, C. and Larcker, D.F. (1981), "Structural equation models with unobservable variables and measurement error: algebra and statistics", Journal of Marketing Research, Vol. 18 No. 3, pp. 382-388. 
Geldes, C., Felzensztein, C., Turkina, E. and Durand, A. (2015), "How does proximity affect inter-firm marketing cooperation? A study of an agribusiness cluster", Journal of Business Research, Vol. 68 No. 2, pp. 263-272.

Geldes, C., Heredia, J., Felzensztein, C. and Mora, M. (2017), "Proximity as determinant of business cooperation for technological and non-technological innovations: a study of an agribusiness cluster", Journal of Business \& Industrial Marketing, Vol. 32 No. 1, pp. 167-178.

Gerbing, D.W. and Anderson, J.C. (1988), "An updated paradigm for scale development: incorporating uni-dimensionality and its assessment", Journal of Marketing Research, Vol. 25 No. 2, pp. 186-192.

Gnyawali, D.R. and Charleton, T.R. (2018), "Nuances in the interplay of competition and cooperation: towards a theory of coopetition", Journal of Management, Vol. 44 No. 7, pp. 2511-2534.

Gnyawali, D.R. and Park, B.J.R. (2009), "Coopetition and technological innovation in small and medium-sized enterprises: a multi-level conceptual model", Journal of Small Business Management, Vol. 47 No. 3, pp. 308-330.

Gnyawali, D.R. and Park, B.J.R. (2011), "Coopetition between giants: collaboration with competitors for technological innovation”, Research Policy, Vol. 40 No. 5, pp. 650-663.

Goulding, C. (2005), "Grounded theory, ethnography and phenomenology: a comparative analysis of three qualitative strategies for marketing research", European Journal of Marketing, Vol. 39 Nos. 3/4, pp. 294-308.

Granata, J., Lasch, F., Le Roy, F. and Dana, L-P. (2018), "How do micro-firms manage coopetition? A study of the wine sector in France", International Small Business Journal, Vol. 36 No. 3, pp. 331-355.

Hair Jr., J.F., Babin, B.J. and Krey, N. (2017), "Covariance-based structural equation modeling in the Journal of Advertising: review and recommendations", Journal of Advertising, Vol. 46 No. 1, pp. 163-177.

Hannah, D.P. and Eisenhardt, K.M. (2018), "How firms navigate cooperation and competition in nascent ecosystems", Strategic Management Journal, Vol. 39 No. 12, pp. 3163-3192.

Hayduk, L.A. and Littvay, L. (2012), "Should researchers use single indicators, best indicators, or multiple indicators in structural equation models?", BMC Medical Research Methodology, Vol. 12 No. 1, pp. 1-17.

Hayton, J.C., Allen, D.G. and Scarpello, V. (2014), "Factor retention decisions in exploratory factor analysis: a tutorial on parallel analysis", Organizational Research Methods, Vol. 7 No. 2, pp. 191-205.

Hodgkinson, I.R., Hughes, P. and Hughes, M. (2012), "Re-examining the deployment of market orientation in the public leisure sector", Journal of Marketing Management, Vol. 28 Nos. 11/12, pp. 1249-1269.

Hong, E. (2011), "Elite sport and nation-building in South Korea: South Korea as the dark horse in global elite sport", International Journal of the History of Sport, Vol. 28 No. 7, pp. 977-989. 
Hulland, J., Baumgartner, H. and Smith, K.M. (2018), "Marketing survey research best practices: evidence and recommendations from a review of JAMS articles", Journal of the Academy of Marketing Science, Vol. 46 No. 1, pp. 92-108.

Hultman, M., Robson, M.J. and Katsikeas, C.S. (2009), "Export product strategy fit and performance: an empirical investigation”, Journal of International Marketing, Vol. 17 No. 4, pp. 1-23.

Hunt, S.D. and Derozier, C. (2004), "The normative imperatives of business and marketing strategy: grounding strategy in resource-advantage theory", Journal of Business \& Industrial Marketing, Vol. 19 No. 1, pp. 5-22.

Hunt, S.D., Sparkman Jr., R.D. and Wilcox, J.B. (1982), "The pre-test in survey research: issues and preliminary findings", Journal of Marketing Research, Vol. 19 No. 2, pp. 269-273.

Jain, M., Khalil, S., Johnston, W.J. and Cheng, J.M.S. (2014), "The performance implications of power-trust relationship: the moderating role of commitment in the supplier-retailer relationship", Industrial Marketing Management, Vol. 43 No. 2, pp. 312-321.

Jaworski, B.J. and Kohli, A.K. (1993), "Market orientation: antecedents and consequences", Journal of Marketing, Vol. 57 No. 3, pp. 53-70.

John, G. and Reve, T. (1982), "The reliability and validity of key informant data from dyadic relationships in marketing channels", Journal of Marketing Research, Vol. 19 No. 4, pp. 517-524.

Kamakura, W.A. and Wedel, M. (2000), "Factor analysis and missing data", Journal of Marketing Research, Vol. 37 No. 4, pp. 490-498.

Katsikeas, C.S., Samiee, S. and Theodosiou, M. (2006), "Strategy fit and performance consequences of international marketing standardization", Strategic Management Journal, Vol. 27 No. 9, pp. 867-890.

Keinanen, H. and Kuivalainen, O. (2015), "Antecedents of social media B2B use in industrial marketing context: customers' view", Journal of Business \& Industrial Marketing, Vol. 30 No. 6, pp. 711-722.

Kim, M.K., Zhang, J.J. and Ko, Y.J. (2009), "Dimensions of market demand associated with Taekwondo schools in North America: development of a scale", Sport Management Review, Vol. 12 No. 3, pp. 149-166.

Kohli, A.K., Jaworski, B.J. and Kumar, A. (1993), "MARKOR: a measure of market orientation", Journal of Marketing Research, Vol. 30 No. 4, pp. 467-477.

Laurent, G. (2000), "Improving the external validity of marketing models: a plea for more qualitative input", International Journal of Research in Marketing, Vol. 17 Nos. 2/3, pp. 177-182.

Lindell, M.K. and Whitney, D.J. (2001), "Accounting for common method variance in cross-sectional research designs", Journal of Applied Psychology, Vol. 86 No. 1, pp. 114-121. 
Lorgnier, N. and Su, C.J. (2014), "Considering coopetition strategies in sport tourism networks: a look at the non-profit nautical sports clubs on the northern coast of France", European Sport Management Quarterly, Vol. 14 No. 1, pp. 87-109.

Lundgren-Henriksson, E-L. and Kock, S. (2016), "A sensemaking perspective on coopetition”, Industrial Marketing Management, Vol. 57 No. 1, pp. 97-108.

Luo, X., Rindfleisch, A. and Tse, D.K. (2007), "Working with rivals: the impact of competitor alliances on financial performance", Journal of Marketing Research, Vol. 44 No. 1, pp. 73-83.

Luo, X., Slotegraaf, R.J. and Pan, X. (2006), "Cross-functional coopetition: the simultaneous role of cooperation and competition within firms", Journal of Marketing, Vol. 70 No. 2, pp. 67-80.

Luo, Y. (2005), "Toward coopetition within a multinational enterprise: a perspective from foreign subsidiaries", Journal of World Business, Vol. 40 No. 1, pp. 71-90.

Malhotra, N.K., Schaller, T.K. and Patil, A. (2017), "Common method variance in advertising research: when to be concerned and how to control for it", Journal of Advertising, Vol. 46 No. 1, pp. 193-212.

Mathias, B.D., Huyghe, A., Frid, C.J. and Galloway, T.L. (2018), "An identity perspective on coopetition in the craft beer industry", Strategic Management Journal, Vol. 39 No. 12, pp. 3086-3115.

Matsuno, K., Mentzer, J.T. and Ozsomer, A. (2002), "The effects of entrepreneurial proclivity and market orientation on business performance", Journal of Marketing, Vol. 66 No. 3, pp. 18-32.

Merkel, U. (2008), "The politics of sport diplomacy and reunification in divided Korea: one nation, two countries and three flags", International Review for the Sociology of Sport, Vol. 43 No. 3, pp. 289-311.

Moorman, C. (1995), "Organizational market information processes: cultural antecedents and new product outcomes", Journal of Marketing Research, Vol. 32 No. 3, pp. 318-335.

Morgan, R.M. and Hunt, S.D. (1994), "The commitment-trust theory of relationship marketing”, Journal of Marketing, Vol. 58 No. 3, pp. 20-38.

Netemeyer, R.G., Bearden, W.O. and Sharma, S. (2003), Scaling Procedures: Issues and Applications, Sage Publications Limited, Thousand Oaks: CA.

Park, B.J.R., Srivastava, M.K. and Gnyawali, D.R. (2014), "Walking the tight rope of coopetition: impact of competition and cooperation intensities and balance on firm innovation performance", Industrial Marketing Management, Vol. 43 No. 2, pp. 210-221.

Peter, J.P. (1981), "Construct validity: a review of basic issues and marketing practices", Journal of Marketing Research, Vol. 18 No. 2, pp. 133-145.

Peterson, R.A. (2000), "A meta-analysis of variance accounted for and factor loadings in exploratory factor analysis", Marketing Letters, Vol. 11 No. 3, pp. 261-275. 
Podsakoff, P.M., Mackenzie, S.B., Lee, J.Y. and Podsakoff, N.P. (2003), "Common method biases in behavioral research: a critical review of the literature and recommended remedies", Journal of Applied Psychology, Vol. 88 No. 5, pp. 879903.

Ranganathan, R., Ghosh, A. and Rosenkopf, L. (2018), "Competition-cooperation interplay during multi-firm technology coordination: the effect of firm heterogeneity on conflict and consensus in a technology standards organization", Strategic Management Journal, Vol. 39 No. 12, pp. 3193-3221.

Raza-Ullah, T., Bengtsson, M. and Kock, S. (2014), "The coopetition paradox and tension in coopetition at multiple-levels", Industrial Marketing Management, Vol. 43 No. 2, pp. 189-198.

Reynolds, N. and Diamantopoulos, A. (1998), "The effect of pre-test method on error detection rates: experimental evidence", European Journal of Marketing, Vol. 32 Nos. 5/6, pp. 480-498.

Rindfleisch, A. and Moorman, C. (2003), "Inter-firm cooperation and customer orientation", Journal of Marketing Research, Vol. 40 No. 4, pp. 421-436.

Ritala, P. (2012), "Coopetition strategy - when is it successful? Empirical evidence on innovation and market performance", British Journal of Management, Vol. 23 No. 3, pp. 307-324.

Ritala, P., Golnam, A. and Wegmann, A. (2014), "Coopetition-based business models: the case of Amazon.com", Industrial Marketing Management, Vol. 43 No. 2, pp. 236-249.

Rocks, S., Gilmore, A. and Carson, D. (2005), "Developing strategic marketing through the use of marketing networks", Journal of Strategic Marketing, Vol. 13 No. 2, pp. $81-92$.

Rossiter, J.R. (2008), "Content validity of measures of abstract constructs in management and organizational research", British Journal of Management, Vol. 19 No. 4 , pp. $380-388$.

Rusko, R. (2011), "Exploring the concept of coopetition: a typology for the strategic moves of the Finnish forest industry", Industrial Marketing Management, Vol. 40 No. 2, pp. 311-320.

Schibrowsky, J.A., Peltier, J.W. and Nill, A. (2007), "The state of internet marketing research: a review of the literature and future research directions", European Journal of Marketing, Vol. 41 Nos. 7/8, pp. 722-733.

Siemsen, E., Roth, A. and Oliveira, P. (2010), "Common method bias in regression models with linear, quadratic, and interaction effects", Organizational Research Methods, Vol. 13 No. 3, pp. 456-476.

Stewart, D.W. (1981), "The application and misapplication of factor analysis in marketing research", Journal of Marketing Research, Vol. 18 No. 1, pp. 51-62.

Suddaby, R. (2006), "From the editors: what grounded theory is not", Academy of Management Journal, Vol. 49 No. 4, pp. 633-642. 
Tidstrom, A. (2014), "Managing tensions in coopetition", Industrial Marketing Management, Vol. 43 No. 2, pp. 261-271.

Tidstrom, A. and Rajala, A. (2016), "Coopetition strategy as interrelated praxis and practices on multiple-levels", Industrial Marketing Management, Vol. 58 No. 1, pp. $35-44$.

Velu, C. (2016), "Evolutionary or revolutionary business model innovation through coopetition? The role of dominance in network markets", Industrial Marketing Management, Vol. 53 No. 1, pp. 124-135.

Virtanen, H. and Kock, S. (2016), "Tension in coopetition between small- and mediumsized firms", Proceedings of the McGill International Entrepreneurship Conference, Vaasa, Finland.

Wang, X. and Yang, Z. (2013), "Inter-firm opportunism: a meta-analytic review and assessment of its antecedents and effect on performance", Journal of Business \& Industrial Marketing, Vol. 28 No. 2, pp. 137-146.

Wetzel, H.A., Hattula, S., Hammerschmidt, M. and van Heerde, H.J. (2018), "Building and leveraging sports brands: evidence from 50 years of German professional soccer", Journal of the Academy of Marketing Science, Vol. 46 No. 4, pp. 591-611.

Yami, S. and Nemeh, A. (2014), "Organizing coopetition for innovation: the case of wireless telecommunication sector in Europe", Industrial Marketing Management, Vol. 43 No. 2, pp. 250-260. 


\section{Codes $^{\text {a }}$ Items \\ In our ITF Taekwon-Do club... (1 = very strongly disagree to 7 = very strongly agree)}

LLC_1 ... we typically lend and borrow assets from rival clubs in this local area

LLC_2 ... we regularly share assets (equipment, etc.) with our local competitors

LLC_3 ... we regularly share equipment with competing clubs in this local vicinity

LLC_4 ... sharing assets with our competitors in a local area is second-nature to us

LLC_5

LLC_6

LLC_7

LLC_8

LLC_9

... we're always lending and borrowing equipment from rival organisations in this area

\section{Assessment of problems}

... we often cooperate with our competitors at a local-level

... we frequently assist our competitors within a close geographic proximity

... collaboration and competition work inter-changeably with rivals in this local area

... cooperation and competition are one of the same things in this local community

LLC_10 ... we frequently help local rivals by sharing assets (equipment, etc.)

LLC 11 ... rival clubs, in this local area, are our allies

LLC_12 .... we regularly trade assets (equipment, etc.) with our local competitors

LLC_13 ... we're always working with rival clubs in this local area

LLC_14 ... we usually collaborate with geographically-close competing organisations

\section{In our ITF Taekwon-Do club... (1 = very strongly disagree to 7 = very strongly agree)}

NLC_1 ... we have great relationships with rival clubs throughout the country

NLC_2 ... we have good ties with rival clubs dotted across the country

NLC_3 3 ... our competitors are our friends in different geographic regions

NLC_4 ... rival clubs are generally viewed as our allies regardless of their geographic region

NLC_5 $\quad . .$. we have positive relationships with competing clubs across the country

NLC_6 $\quad .$. we are highly-collaborative with rival clubs in different parts of the country

NLC_ $7 \quad \ldots$ we try to share resources and capabilities with competing clubs across the country

NLC_8 $\quad \ldots$ we are highly-cooperative with our competitors in other regions

NLC_9 ... we try to share assets (equipment, etc.) with competitors in different regions

NLC_10 ... we collaborate with our competitors all over the country

NLC_11 ... we share resources and capabilities with our rivals outside of our own region

NLC_12 ... we're always lending and borrowing equipment from competitors in different regions

$\mathrm{NLC}^{-} 13 \quad \ldots$ we frequently share assets (equipment, etc.) with competitors outside of our own region

NLC_14 ... we're prepared to share assets with our competitors regardless of their region

\begin{tabular}{|c|c|c|}
\hline \multicolumn{3}{|c|}{ Assessment of problems } \\
\hline Frequency & Percentage & Retained \\
\hline 21 & 70.00 & No \\
\hline 0 & 0.00 & Yes \\
\hline 25 & 83.33 & No \\
\hline 19 & 63.33 & No \\
\hline 16 & 53.33 & No \\
\hline 0 & 0.00 & Yes \\
\hline 29 & 96.67 & No \\
\hline 15 & 50.00 & No \\
\hline 24 & 80.00 & No \\
\hline 0 & 0.00 & Yes \\
\hline 25 & 83.33 & No \\
\hline 21 & 70.00 & No \\
\hline 16 & 53.00 & No \\
\hline 0 & 0.00 & Yes \\
\hline & & \\
\hline 29 & 96.67 & No \\
\hline 24 & 80.00 & No \\
\hline 20 & 66.67 & No \\
\hline 21 & 70.00 & No \\
\hline 0 & 0.00 & Yes \\
\hline 20 & 66.67 & No \\
\hline 29 & 96.67 & No \\
\hline 0 & 0.00 & Yes \\
\hline 30 & 100.00 & No \\
\hline 25 & 83.33 & No \\
\hline 21 & 70.00 & No \\
\hline 20 & 66.67 & No \\
\hline 0 & 0.00 & Yes \\
\hline 30 & 100.00 & No \\
\hline & & \\
\hline
\end{tabular}




\begin{tabular}{|c|c|c|c|c|}
\hline NLC_15 & ... collaboration across geographic regions is second-nature to us & 25 & 83.33 & No \\
\hline NLC 16 & ... we collaborate with our competitors in multiple regions & 0 & 0.00 & Yes \\
\hline NLC_-17 & ... cooperating with rival clubs in different parts of the country is highly-common & 21 & 70.00 & No \\
\hline & In our ITF Taekwon-Do club... ( 1 = very strongly disagree to 7 = very strongly agree) & & & \\
\hline OLC_1 & ... we're prepared to share resources and capabilities from indirect competitors & 20 & 66.67 & No \\
\hline OLC_2 & ... we share assets (equipment, etc.) with indirect competitors & 21 & 70.00 & No \\
\hline OLC_3 & $\ldots$ we are very collaborative with indirect competitors & 29 & 96.67 & No \\
\hline OLC_4 & ... we regularly cooperate with non-ITF Taekwon-Do competing organisations & 0 & 0.00 & Yes \\
\hline OLC_5 & ... we typically share resources and capabilities with different sporting organisations & 30 & 100.00 & No \\
\hline OLC_6 & ... we borrow and lend assets (equipment, etc.) from non-ITF Taekwon-Do organisations & 25 & 83.33 & No \\
\hline OLC_- 7 & ... our members are always sharing equipment with rival sporting organisations & 20 & 66.67 & No \\
\hline OLC_8 8 & ... we frequently work with non-ITF Taekwon-Do organisations & 16 & 53.33 & No \\
\hline OLC_9 & ... we have positive ties with non-ITF Taekwon-Do martial arts organisations & 0 & 0.00 & Yes \\
\hline OLC_10 & $\ldots$ we are highly-cooperative with sporting clubs that offer different services to us & 20 & 66.67 & No \\
\hline OLC 11 & ... we regularly collaborate with non-ITF Taekwon-Do competing organisations & 25 & 83.33 & No \\
\hline OLC_12 & $\ldots$ we often share assets (equipment etc.) with non-ITF Taekwon-Do organisations & 0 & 0.00 & Yes \\
\hline OLC_13 & ... we frequently pool assets (equipment, etc.) with rival sporting organisations & 0 & 0.00 & Yes \\
\hline
\end{tabular}

coopetition. 
Table 2. Characteristics of the final sample

\begin{tabular}{|l|l|c|c|c|c|}
\hline Codes $^{\mathbf{a}}$ & Variables & Mean & SD & Min & Max \\
\hline EXP_1 & Years training in Taekwon-Do & 21.54 & 9.02 & 2.30 & 65.00 \\
\hline EXP_2 & Years as a Taekwon-Do instructor & 12.38 & 7.73 & 0.00 & 39.30 \\
\hline SIZE_1 & Number of Taekwon-Do students & 70.01 & 42.31 & 3.00 & 300.00 \\
\hline SIZE_2 & Number of Taekwon-Do instructors & 5.27 & 4.86 & 1.00 & 59.00 \\
\hline AGE & Age of the Taekwon-Do clubs (years) & 31.67 & 7.63 & 9.00 & 47.00 \\
\hline
\end{tabular}

Notes: ${ }^{a}$ All these variables were originally-developed for this investigation. 


\begin{tabular}{|c|c|c|c|c|c|}
\hline Codes $^{a}$ & Items & Mean & SD & Min & Max \\
\hline & In our ITF Taekwon-Do club... (1 = very strongly disagree to 7 = very strongly agree) & & & & \\
\hline LLC_1 & $\ldots$ we regularly share assets (equipment, etc.) with our local competitors & 4.00 & 1.11 & 1.00 & 7.00 \\
\hline LLC_2 & ... we frequently help local rivals by sharing assets (equipment, etc.) & 3.89 & 1.12 & 1.00 & 7.00 \\
\hline LLC_3 & ... we often cooperate with our competitors at a local-level & 4.76 & 0.99 & 1.00 & 7.00 \\
\hline \multirow[t]{2}{*}{ LLC_4 } & ... we usually collaborate with geographically-close competing organisations & 4.59 & 1.01 & 1.00 & 7.00 \\
\hline & In our ITF Taekwon-Do club... (1 = very strongly disagree to 7 = very strongly agree) & & & & \\
\hline NLC_1 & ... we have positive relationships with competing clubs across the country & 5.27 & 0.85 & 1.00 & 7.00 \\
\hline NLC_2 & ... we are highly-cooperative with our competitors in other regions & 4.94 & 0.93 & 1.00 & 7.00 \\
\hline NLC_3 & ... we frequently share assets (equipment, etc.) with competitors outside of our own region & 4.53 & 0.95 & 1.00 & 7.00 \\
\hline \multirow[t]{2}{*}{ NLC_4 } & $\ldots$ we collaborate with our competitors in multiple regions & 4.75 & 0.92 & 1.00 & 7.00 \\
\hline & In our ITF Taekwon-Do club... ( 1 = very strongly disagree to 7 = very strongly agree) & & & & \\
\hline OLC_1 & ... we regularly cooperate with non-ITF Taekwon-Do competing organisations & 4.10 & 0.91 & 1.00 & 7.00 \\
\hline OLC_2 & ... we have positive ties with non-ITF Taekwon-Do martial arts organisations & 3.70 & 0.89 & 1.00 & 7.00 \\
\hline OLC_3 & ... we often share assets (equipment etc.) with non-ITF Taekwon-Do organisations & 3.08 & 0.94 & 1.00 & 7.00 \\
\hline \multirow[t]{2}{*}{ OLC_4 } & ... we frequently pool assets (equipment, etc.) with rival sporting organisations & 3.11 & 0.83 & 1.00 & 7.00 \\
\hline & In closing to the survey: ( 1 = very strongly disagree to 7 = very strongly agree) & & & & \\
\hline INQ_1 & I am confident about my answers to the questions & 5.61 & 0.73 & 2.00 & 7.00 \\
\hline INQ_2 & I am confident that my answers reflect our club's situation & 5.64 & 0.63 & 4.00 & 7.00 \\
\hline INQ_3 & This survey deals with issues I am very knowledgeable about & 5.51 & 0.76 & 3.00 & 7.00 \\
\hline INQ_4 & My current role qualifies me as an appropriate person to complete this survey & 5.89 & 0.73 & 3.00 & 7.00 \\
\hline \multirow[t]{2}{*}{ INQ_5 } & I am competent to answer the above questions & 5.89 & 0.73 & 4.00 & 7.00 \\
\hline & In the ITF... (1 = very strongly disagree to 7 = very strongly disagree) & & & & \\
\hline COM_1 & ... members are cooperative across competing clubs & 4.82 & 1.02 & 1.00 & 7.00 \\
\hline COM_2 & ... members believe in assisting other clubs & 4.90 & 1.02 & 1.00 & 7.00 \\
\hline COM_3 & $\ldots$ all rival clubs should cooperate with one another & 5.11 & 1.05 & 1.00 & 7.00 \\
\hline COM_4 & ... clubs should share assets (e.g., equipment) with competing clubs as much as possible & 4.37 & 0.93 & 1.00 & 7.00 \\
\hline COM_5 & $\ldots$ it is important for members to be collaborative with rival clubs & 4.97 & 0.99 & 1.00 & 7.00 \\
\hline \multirow[t]{2}{*}{ COM_6 } & ... we have an organisational culture that focuses on cooperating with competing clubs & 4.82 & 1.09 & 1.00 & 7.00 \\
\hline & In our ITF Taekwon-Do club's environment... (1 = very strongly disagree to 7 = very strongly agree) & & & & \\
\hline COMP_1 & ... competition for student membership is cut-throat & 3.17 & 1.14 & 1.00 & 7.00 \\
\hline COMP_2 & ... anything that one club can offer, others can match readily & 4.19 & 0.88 & 1.00 & 7.00 \\
\hline COMP_3 & $\ldots$ our rival clubs are relatively strong & 4.49 & 0.79 & 1.00 & 7.00 \\
\hline
\end{tabular}

from informant quality, COM is a coopetition-oriented mind-set, and COMP represents competitive intensity. 
Table 4. Exploratory factor analysis results

\begin{tabular}{|c|c|c|c|c|c|c|c|c|c|c|c|c|}
\hline \multirow[b]{2}{*}{ Items $^{a}$} & \multicolumn{4}{|c|}{$\begin{array}{c}\text { Model 1: Components (principal } \\
\text { components analysis extraction and a } \\
\text { varimax rotation) }\end{array}$} & \multicolumn{4}{|c|}{$\begin{array}{c}\text { Model 2: Components (maximum } \\
\text { likelihood extraction and a varimax } \\
\text { rotation) }\end{array}$} & \multicolumn{4}{|c|}{$\begin{array}{l}\text { Model 3: Components (principal axis } \\
\text { factoring extraction and a direct oblimin } \\
\text { rotation) }\end{array}$} \\
\hline & 1 & 2 & 3 & 4 & 1 & 2 & 3 & 4 & 1 & 2 & 3 & 4 \\
\hline LLC_1 & 0.91 & 0.14 & 0.20 & 0.06 & 0.94 & 0.18 & 0.15 & 0.07 & 0.95 & 0.36 & 0.42 & 0.10 \\
\hline LLC_2 & 0.92 & 0.15 & 0.23 & 0.02 & 0.96 & 0.18 & 0.16 & 0.03 & 0.97 & 0.36 & 0.45 & 0.06 \\
\hline LLC_3 & 0.81 & 0.34 & 0.21 & 0.03 & 0.69 & 0.35 & 0.26 & 0.05 & 0.83 & 0.52 & 0.45 & 0.07 \\
\hline LLC_4 & 0.80 & 0.31 & 0.16 & 0.06 & 0.66 & 0.34 & 0.21 & 0.08 & 0.80 & 0.49 & 0.41 & 0.11 \\
\hline NLC_1 & 0.10 & 0.86 & 0.17 & 0.02 & 0.12 & 0.78 & 0.18 & 0.05 & 0.27 & 0.82 & 0.36 & 0.06 \\
\hline NLC_2 & 0.25 & 0.85 & 0.21 & 0.07 & 0.22 & 0.87 & 0.21 & 0.04 & 0.41 & 0.90 & 0.42 & 0.11 \\
\hline NLC_3 & 0.20 & 0.81 & 0.06 & 0.01 & 0.21 & 0.70 & 0.11 & 0.07 & 0.33 & 0.75 & 0.28 & 0.06 \\
\hline NLC_4 & 0.26 & 0.85 & 0.21 & 0.06 & 0.27 & 0.86 & 0.19 & 0.06 & 0.42 & 0.90 & 0.42 & 0.11 \\
\hline OLC_1 & 0.13 & 0.30 & 0.80 & 0.00 & 0.14 & 0.28 & 0.81 & -0.01 & 0.32 & 0.45 & 0.81 & 0.01 \\
\hline OLC_2 & 0.03 & 0.27 & 0.86 & 0.01 & 0.09 & 0.24 & 0.87 & 0.00 & 0.24 & 0.41 & 0.87 & 0.02 \\
\hline OLC_3 & 0.36 & 0.10 & 0.80 & 0.05 & 0.46 & 0.14 & 0.65 & 0.04 & 0.51 & 0.32 & 0.82 & 0.07 \\
\hline OLC_4 & 0.34 & 0.00 & 0.73 & -0.07 & 0.41 & 0.07 & 0.54 & -0.06 & 0.43 & 0.22 & 0.68 & -0.06 \\
\hline INQ_1 & 0.18 & -0.04 & -0.09 & 0.85 & 0.16 & 0.07 & -0.10 & 0.74 & 0.17 & 0.02 & -0.06 & 0.80 \\
\hline$I N Q \_2$ & 0.10 & 0.01 & -0.06 & 0.95 & 0.09 & 0.04 & -0.07 & 0.86 & 0.13 & 0.07 & -0.04 & 0.95 \\
\hline INQ_3 & 0.04 & 0.01 & 0.07 & 0.87 & 0.07 & 0.04 & 0.04 & 0.78 & 0.09 & 0.08 & 0.06 & 0.82 \\
\hline INQ_4 & -0.05 & 0.09 & 0.05 & 0.94 & -0.05 & 0.07 & 0.07 & 0.98 & 0.00 & 0.13 & 0.04 & 0.94 \\
\hline INQ_5 & -0.10 & 0.11 & 0.02 & 0.93 & -0.11 & 0.08 & 0.06 & 0.96 & -0.03 & 0.13 & 0.02 & 0.92 \\
\hline $\mathrm{S}^{2}(\%)$ & 23.80 & 10.75 & 9.53 & 36.98 & 22.36 & 15.54 & 8.07 & 28.62 & 35.56 & 9.41 & 7.89 & 22.66 \\
\hline
\end{tabular}

Notes: aLC represents local-level coopetition, NLC stands for national-level coopetition, OLC is abbreviated from organisation-level coopetition, and INQ is shortened from informant quality. 
Table 5. Confirmatory factor analysis results

\begin{tabular}{|c|c|c|c|c|c|c|c|c|c|}
\hline & \multicolumn{10}{|c|}{ Model fit indices $^{\mathbf{a}}$} \\
\hline Model & $\mathbf{X}^{\mathbf{2}}$ & Sig. & $\mathbf{d f}$ & $\mathbf{X}^{2} / \mathbf{d f}$ & $\mathbf{R M S E A}$ & $\mathbf{N N F I}$ & $\mathbf{C F I}$ & IFI & SRMR \\
\hline Set 1 & 354.89 & 0.00 & 51 & 6.95 & 0.20 & 0.78 & 0.83 & 0.83 & 0.09 \\
\hline Set 2 & 9.37 & 0.15 & 6 & 1.56 & 0.06 & 0.99 & 0.99 & 0.99 & 0.03 \\
\hline
\end{tabular}

Notes: ${ }^{\text {Set }} 1$ included all items retained after the three exploratory factor analysis models. Set 2 was the confirmatory factor analysis after the problematic items were deleted (used in the final operationalisation of the coopetition construct). 
Table 6. Measures after the scale purification stage

\begin{tabular}{|c|c|c|c|c|c|}
\hline Codes & Items $^{\mathbf{a}}$ & $\begin{array}{l}\text { Factor } \\
\text { loadings }\end{array}$ & $\begin{array}{c}\text { Error } \\
\text { variances }\end{array}$ & $t$-values ${ }^{b}$ & $\begin{array}{c}\text { Retained } \\
\text { items }\end{array}$ \\
\hline & In our ITF Taekwon-Do club... (1 = very strongly disagree to 7 = very strongly agree) & & & & \\
\hline LLC_1 & ... we regularly share assets (equipment, etc.) with our local competitors & 0.97 & 0.07 & Fixed & Yes \\
\hline LLC_2 & ... we frequently help local rivals by sharing assets (equipment, etc.) & 0.99 & 0.02 & 19.58 & Yes \\
\hline LLC_3 & ... we often cooperate with our competitors at a local-level & 0.80 & 0.37 & 15.23 & No \\
\hline \multirow[t]{2}{*}{ LLC_4 } & ... we usually collaborate with geographically-close competing organisations & 0.75 & 0.43 & 13.40 & No \\
\hline & In our ITF Taekwon-Do club... ( 1 = very strongly disagree to 7 = very strongly agree) & & & & \\
\hline NLC_1 & ... we have positive relationships with competing clubs across the country & 0.80 & 0.43 & Fixed & Yes \\
\hline NLC_2 & ... we are highly-cooperative with our competitors in other regions & 0.90 & 0.18 & 10.08 & No \\
\hline NLC_3 & ... we frequently share assets (equipment, etc.) with competitors outside of our own region & 0.74 & 0.45 & 13.92 & No \\
\hline \multirow[t]{2}{*}{ NLC_4 4} & ... we collaborate with our competitors in multiple regions & 0.99 & 0.02 & 7.61 & Yes \\
\hline & In our ITF Taekwon-Do club... ( 1 = very strongly disagree to 7 = very strongly agree) & & & & \\
\hline OLC_1 & ... we regularly cooperate with non-ITF Taekwon-Do competing organisations & 0.90 & 0.19 & Fixed & Yes \\
\hline OLC_2 & ... we have positive ties with non-ITF Taekwon-Do martial arts organisations & 0.89 & 0.21 & 8.16 & Yes \\
\hline OLC_3 & ... we often share assets (equipment etc.) with non-ITF Taekwon-Do organisations & 0.79 & 0.37 & 11.02 & No \\
\hline OLC_4 & ... we frequently pool assets (equipment, etc.) with rival sporting organisations & 0.65 & 0.58 & 8.52 & No \\
\hline
\end{tabular}

Notes: The informant quality (INQ), coopetition-oriented mind-set (COM), and competitive intensity (COMP) items were not included within this table, as they were primarily used to test for common method variance under the marker variable technique. Also, these items were not included within the confirmatory factor analysis, meaning that the factor loadings $(\lambda x)$, error variances $(\theta \delta)$, and $t$-values were not calculated. LLC represents local-level coopetition, NLC stands for national-level coopetition, and OLC is abbreviated from organisation-level coopetition.

${ }^{\mathrm{b}}$ The critical $t$-value was 1.65 (5\%, one-sided). 
Table 7. Final scale reliabilities and the discriminant validity test

\begin{tabular}{|c|c|c|c|c|c|c|}
\hline \multirow[b]{2}{*}{ Variables $^{a}$} & \multicolumn{3}{|c|}{ Final scale reliabilities } & \multicolumn{3}{|c|}{ Discriminant validity test } \\
\hline & Alpha $(\alpha)$ & CR & AVE & 1 & 2 & 3 \\
\hline 1. Local-level coopetition & 0.98 & 0.98 & 0.96 & 1.00 & & \\
\hline 2. National-level coopetition & 0.86 & 0.88 & 0.78 & 0.22 & 1.00 & \\
\hline 3. Organisation-level coopetition & 0.89 & 0.89 & 0.80 & 0.22 & 0.26 & 1.00 \\
\hline
\end{tabular}


Table 8. Correlation matrix for the nomological validity test

\begin{tabular}{|c|c|c|c|c|c|c|c|c|c|}
\hline Variables $^{a}$ & Mean & SD & 1 & 2 & 3 & 4 & 5 & 6 & 7 \\
\hline 1. Coopetition-oriented mind-set & 4.83 & 0.86 & 1.00 & & & & & & \\
\hline 2. Local-level coopetition & 3.94 & 1.10 & 0.62 & 1.00 & & & & & \\
\hline 3. National-level coopetition & 5.01 & 0.83 & 0.64 & 0.39 & 1.00 & & & & \\
\hline 4. Organisation-level coopetition & 3.90 & 0.86 & 0.46 & 0.30 & 0.43 & 1.00 & & & \\
\hline 5. Firm size & 4.17 & 0.61 & -0.14 & 0.11 & 0.09 & -0.13 & 1.00 & & \\
\hline 6. Firm age & 3.42 & 0.27 & 0.10 & -0.15 & 0.12 & 0.17 & -0.22 & 1.00 & \\
\hline 7. Competitive intensity & 4.13 & 0.71 & -0.24 & -0.24 & -0.09 & -0.38 & -0.16 & -0.14 & 1.00 \\
\hline
\end{tabular}


Table 9. OLS multiple regression analyses used for the nomological validity test

\begin{tabular}{|c|c|c|c|c|c|c|c|c|c|}
\hline \multirow[b]{2}{*}{ Independent variables ${ }^{a}$ : } & \multicolumn{3}{|c|}{$\begin{array}{l}\text { Local-level coopetition } \\
\text { (Model 1) }\end{array}$} & \multicolumn{3}{|c|}{$\begin{array}{l}\text { National-level coopetition } \\
\text { (Model 2) }\end{array}$} & \multicolumn{3}{|c|}{$\begin{array}{c}\text { Organisation-level coopetition } \\
\text { (Model 3) }\end{array}$} \\
\hline & $\beta$ & $t$-values & Sig. & $\beta$ & $t$-values & Sig. & $\beta$ & $t$-values & Sig. \\
\hline Coopetition-oriented mind-set & 0.72 & 11.51 & 0.00 & 0.59 & 9.20 & 0.00 & 0.44 & 5.73 & 0.00 \\
\hline \multicolumn{10}{|l|}{ Controls: } \\
\hline Firm size & 0.17 & 2.68 & 0.01 & 0.08 & 1.27 & 0.21 & -0.05 & -0.71 & 0.48 \\
\hline Firm age & -0.17 & -2.57 & 0.01 & 0.04 & 0.64 & 0.52 & 0.10 & 1.34 & 0.18 \\
\hline Competitive intensity & 0.07 & 1.11 & 0.27 & -0.22 & -3.36 & 0.00 & -0.05 & -0.62 & 0.54 \\
\hline \multicolumn{10}{|l|}{ Model fit summary: } \\
\hline $\mathrm{R}$ & 0.67 & & & 0.68 & & & 0.48 & & \\
\hline $\mathrm{R}^{2}$ & 0.45 & & & 0.46 & & & 0.23 & & \\
\hline Adjusted $R^{2}$ & 0.44 & & & 0.45 & & & 0.21 & & \\
\hline F-statistic & 29.88 & & & 31.53 & & & 10.78 & & \\
\hline Sig. & 0.00 & & & 0.00 & & & 0.00 & & \\
\hline
\end{tabular}


Appendix 1. Empirical studies used to develop and validate a multi-dimensional measure of coopetition

\begin{tabular}{|c|c|c|c|c|}
\hline Study ${ }^{a}$ & Sample (n) & Core data collection methods ${ }^{b}$ & Purpose & Core data analysis methods \\
\hline 1 & 25 & $\begin{array}{l}\text { Semi-structured interviews with the } \\
\text { instructors of sporting organisations }\end{array}$ & $\begin{array}{l}\text { To enquire into the multiple forms of } \\
\text { coopetition }\end{array}$ & $\begin{array}{l}\text { A thematic content analysis, with } \\
\text { pre-determined themes. }\end{array}$ \\
\hline 2 & 59 & $\begin{array}{l}\text { Electronic survey distributed to the } \\
\text { instructors of sporting organisations }\end{array}$ & $\begin{array}{l}\text { To investigate the cooperative and } \\
\text { competitive empirical context }\end{array}$ & $\begin{array}{l}\text { Descriptive statistics and scale } \\
\text { frequencies. }\end{array}$ \\
\hline 3 & 20 & $\begin{array}{l}\text { Pre-testing an electronic survey with } \\
\text { sporting organisations }\end{array}$ & $\begin{array}{l}\text { To obtain feedback on the survey } \\
\text { before it was administered }\end{array}$ & $\begin{array}{l}\text { A thematic content analysis, with } \\
\text { emergent themes. }\end{array}$ \\
\hline 4 & 10 & $\begin{array}{l}\text { Pre-testing an electronic survey with } \\
\text { marketing academics }\end{array}$ & $\begin{array}{l}\text { To receive advice on the survey } \\
\text { before it was administered }\end{array}$ & $\begin{array}{l}\text { ontent analysis, with } \\
\text { mes. }\end{array}$ \\
\hline 5 & 31 & $\begin{array}{l}\text { A pilot study, using an electronic survey } \\
\text { distributed to sporting organisations }\end{array}$ & $\begin{array}{l}\text { To assess prelimin } \\
\text { before the core study }\end{array}$ & $\begin{array}{l}\text { Descriptive statistics (as well as } \\
\text { frequencies) and scale reliabilities. }\end{array}$ \\
\hline 6 & 120 & $\begin{array}{l}\text { A core study, involving an electronic survey } \\
\text { distributed to sporting organisations }\end{array}$ & $\begin{array}{l}\text { To develop and validate a multi- } \\
\text { dimensional scale for coopetition }\end{array}$ & $\begin{array}{l}\text { Descriptive statis } \\
\text { reliabilities, and factc }\end{array}$ \\
\hline \multicolumn{5}{|c|}{ 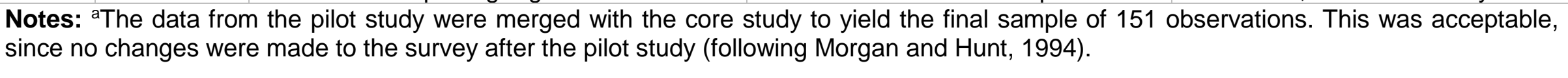 } \\
\hline \multicolumn{5}{|c|}{$\begin{array}{l}\text { bIn tandem with the empirical data, the researchers obtained access to several sources of archival data (like financial statements, websites } \\
\text { and promotional sources). Such archival data helped obtain a deeper understanding of the sporting governing body in New Zealand to } \\
\text { supplement the empirical data. }\end{array}$} \\
\hline
\end{tabular}




\section{Appendix 2. Inter-item correlations}

\begin{tabular}{|c|c|c|c|c|c|c|c|c|c|c|c|c|c|c|c|c|c|}
\hline Items $^{\text {ab }}$ & 1 & 2 & 3 & 4 & 5 & 6 & 7 & 8 & 9 & 10 & 11 & 12 & 13 & 14 & 15 & 16 & 17 \\
\hline 1. LLC_1 & 1.00 & & & & & & & & & & & & & & & & \\
\hline 2. LLC_2 & 0.96 & 1.00 & & & & & & & & & & & & & & & \\
\hline 3. LLC_3 & 0.77 & 0.76 & 1.00 & & & & & & & & & & & & & & \\
\hline 4. LLC_4 & 0.71 & 0.72 & 0.90 & 1.00 & & & & & & & & & & & & & \\
\hline 5. NLC_1 & 0.27 & 0.29 & 0.40 & 0.35 & 1.00 & & & & & & & & & & & & \\
\hline 6. NLC_2 & 0.39 & 0.40 & 0.52 & 0.52 & 0.73 & 1.00 & & & & & & & & & & & \\
\hline 7. NLC_3 & 0.35 & 0.35 & 0.42 & 0.39 & 0.64 & 0.65 & 1.00 & & & & & & & & & & \\
\hline 8. NLC_4 & 0.43 & 0.45 & 0.48 & 0.47 & 0.75 & 0.86 & 0.70 & 1.00 & & & & & & & & & \\
\hline 9. OLC_1 & 0.31 & 0.31 & 0.51 & 0.42 & 0.38 & 0.48 & 0.27 & 0.39 & 1.00 & & & & & & & & \\
\hline 10. OLC_2 & 0.25 & 0.26 & 0.37 & 0.31 & 0.34 & 0.40 & 0.31 & 0.41 & 0.80 & 1.00 & & & & & & & \\
\hline 11. OLC_3 & 0.53 & 0.58 & 0.40 & 0.40 & 0.30 & 0.37 & 0.26 & 0.39 & 0.61 & 0.64 & 1.00 & & & & & & \\
\hline 12. OLC_4 & 0.45 & 0.49 & 0.33 & 0.34 & 0.23 & 0.24 & 0.17 & 0.30 & 0.44 & 0.52 & 0.71 & 1.00 & & & & & \\
\hline 13. INQ_1 & 0.17 & 0.15 & 0.09 & 0.16 & -0.04 & 0.09 & -0.08 & 0.10 & -0.07 & -0.05 & 0.08 & -0.10 & 1.00 & & & & \\
\hline 14. INQ_2 & 0.12 & 0.10 & 0.10 & 0.14 & 0.04 & 0.13 & 0.05 & 0.08 & -0.04 & -0.04 & 0.07 & -0.08 & 0.84 & 1.00 & & & \\
\hline 15. INQ_3 & 0.13 & 0.10 & 0.08 & 0.07 & 0.08 & 0.14 & 0.17 & 0.10 & 0.06 & 0.06 & 0.09 & 0.02 & 0.64 & 0.83 & 1.00 & & \\
\hline 16. INQ_4 & 0.04 & -0.00 & 0.05 & 0.07 & 0.11 & 0.10 & 0.13 & 0.12 & 0.05 & 0.06 & 0.07 & -0.03 & 0.69 & 0.83 & 0.76 & 1.00 & \\
\hline 17. INQ_5 & 0.00 & -0.05 & 0.02 & 0.06 & 0.13 & 0.10 & 0.09 & 0.11 & 0.05 & 0.06 & 0.02 & -0.10 & 0.69 & 0.80 & 0.73 & 0.96 & 1.00 \\
\hline
\end{tabular}

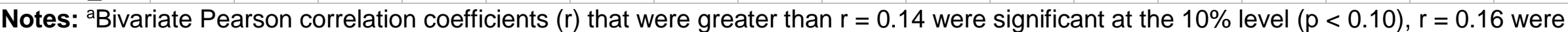
significant at the $5 \%$ level $(p<0.05)$, and $r=0.23$ were significant at the $1 \%$ level $(p<0.01)($ all two-tailed tests).

bLCC represents local-level coopetition, NLC stands for national-level coopetition, OLC is abbreviated from organisation-level coopetition, and INQ is shortened from informant quality. 


\section{Appendix 3. Jack-knife procedure results}

\begin{tabular}{|c|c|c|c|c|c|c|c|c|c|}
\hline \multirow[b]{2}{*}{ Independent variables ${ }^{a}$ : } & \multicolumn{3}{|c|}{ Local-level coopetition (Model 1) } & \multicolumn{3}{|c|}{ National-level coopetition (Model 2) } & \multicolumn{3}{|c|}{ Organisation-level coopetition (Model 3) } \\
\hline & $\beta$ & $t$-values & Sig. & $\beta$ & $t$-values & Sig. & $\beta$ & $t$-values & Sig. \\
\hline $\begin{array}{l}\text { Coopetition-oriented mind- } \\
\text { set }\end{array}$ & $\begin{array}{l}0.70(0.72) \\
0.69-0.71\end{array}$ & $\begin{array}{l}6.93(11.51) \\
6.83-7.79\end{array}$ & $\begin{array}{l}0.00(0.00) \\
0.00-0.01\end{array}$ & $\begin{array}{l}0.44(0.59) \\
0.43-0.52\end{array}$ & $\begin{array}{l}4.47(9.20) \\
4.30-5.12\end{array}$ & $\begin{array}{l}0.00(0.00) \\
0.01-0.07\end{array}$ & $\begin{array}{l}0.44(0.47) \\
0.41-0.53\end{array}$ & $\begin{array}{l}3.63(5.73) \\
3.10-3.42\end{array}$ & $\begin{array}{l}0.02(0.00) \\
0.01-0.03\end{array}$ \\
\hline \multicolumn{10}{|l|}{ Controls: } \\
\hline Firm size & $\begin{array}{l}0.07(0.17) \\
0.05-0.09\end{array}$ & $\begin{array}{l}0.88(2.65) \\
0.66-1.11\end{array}$ & $\begin{array}{l}0.49(0.01) \\
0.42-0.54\end{array}$ & $\begin{array}{c}0.01(0.08) \\
-0.01-0.02\end{array}$ & $\begin{array}{l}0.19(1.27) \\
0.03-0.33\end{array}$ & $\begin{array}{l}0.63(0.21) \\
0.58-0.68\end{array}$ & $\begin{array}{l}-0.10(-0.05) \\
-0.10--0.12\end{array}$ & $\begin{array}{l}-0.77(-0.71) \\
-0.58--0.72\end{array}$ & $\begin{array}{l}0.44(0.48) \\
0.41-0.49\end{array}$ \\
\hline Firm age & $\begin{array}{l}-0.18(-0.17) \\
-0.19--0.18\end{array}$ & $\begin{array}{l}-2.07(-2.57) \\
-2.20--1.94\end{array}$ & $\begin{array}{l}0.07(0.01) \\
0.06-0.09\end{array}$ & $\begin{array}{c}0.00(0.07) \\
-0.02-0.19\end{array}$ & $\begin{array}{l}0.30(0.04) \\
0.15-0.44\end{array}$ & $\begin{array}{l}0.58(0.52) \\
0.48-0.55\end{array}$ & $\begin{array}{l}0.20(0.10) \\
0.19-0.21\end{array}$ & $\begin{array}{l}1.32(1.34) \\
1.21-1.44\end{array}$ & $\begin{array}{l}0.28(0.18) \\
0.24-0.32\end{array}$ \\
\hline Competitive intensity & $\begin{array}{l}-0.19(-0.07) \\
-0.19--0.21\end{array}$ & $\begin{array}{l}-2.07(1.11) \\
2.23-2.49\end{array}$ & $\begin{array}{l}0.07(0.27) \\
0.00-0.09\end{array}$ & $\begin{array}{l}-0.24(-0.22) \\
-0.26--0.22\end{array}$ & $\begin{array}{l}-2.00(-3.36) \\
-2.12-1.92\end{array}$ & $\begin{array}{l}0.06(0.00) \\
0.05-0.09\end{array}$ & $\begin{array}{l}-0.03(-0.05) \\
-0.02--0.07\end{array}$ & $\begin{array}{c}0.00(-0.62) \\
-0.02-0.00\end{array}$ & $\begin{array}{l}-0.15(0.54) \\
-0.23-0.07\end{array}$ \\
\hline \multicolumn{10}{|l|}{ Model fit summary: } \\
\hline $\mathrm{R}$ & $\begin{array}{l}0.72(0.67) \\
0.71-0.72\end{array}$ & & & $\begin{array}{l}0.63(0.68) \\
0.61-0.65\end{array}$ & & & $\begin{array}{l}0.50(0.48) \\
0.48-0.53\end{array}$ & & \\
\hline $\mathrm{R}^{2}$ & $\begin{array}{l}0.52(0.45) \\
0.51-0.53\end{array}$ & & & $\begin{array}{l}0.40(0.46) \\
0.38-0.43\end{array}$ & & & $\begin{array}{l}0.30(0.23) \\
0.25-0.32\end{array}$ & & \\
\hline Adjusted $\mathrm{R}^{2}$ & $\begin{array}{l}0.46(0.44) \\
0.45-0.47\end{array}$ & & & $\begin{array}{l}0.36(0.45) \\
0.34-0.38\end{array}$ & & & $\begin{array}{l}0.23(0.21) \\
0.20-0.25\end{array}$ & & \\
\hline$F$-statistic & $\begin{array}{l}17.05(29.88) \\
16.01-19.28\end{array}$ & & & $\begin{array}{l}10.91(31.53) \\
9.52-11.41\end{array}$ & & & $\begin{array}{l}5.11(10.78) \\
4.59-5.24\end{array}$ & & \\
\hline Sig. & $\begin{array}{l}0.01(0.00) \\
0.00-0.02\end{array}$ & & & $\begin{array}{l}0.00(0.00) \\
0.00-0.01\end{array}$ & & & $\begin{array}{l}0.01(0.00) \\
0.01-0.03\end{array}$ & & \\
\hline
\end{tabular}

Notes: aln each cell, the first row represents the average (mean) value from the jack-knife procedure, with the value from the final sample in parentheses $(n=151)$. The second row outlines the $95 \%$ confidence intervals used in the jack-knife procedure, with the lower bound on the left and the upper bound on the right. The critical $t$-value was 1.65 ( $5 \%$, two-sided). 
Appendix 4. Marker variable technique for common method variance

\begin{tabular}{|c|c|c|c|c|c|c|c|c|c|}
\hline & \multicolumn{3}{|c|}{ Model 1} & \multicolumn{3}{|c|}{ Model 2} & \multicolumn{3}{|c|}{ Model 3} \\
\hline Variables $^{a}$ & 1 & 2 & 3 & 1 & 2 & 3 & 1 & 2 & 3 \\
\hline 1. Local-level coopetition & 1.00 & & & 1.00 & & & 0.00 & & \\
\hline 2. National-level coopetition & 0.39 & 1.00 & & 0.38 & 1.00 & & 0.01 & 0.00 & \\
\hline 3. Organisation-level coopetition & 0.30 & 0.43 & 1.00 & 0.30 & 0.43 & 1.00 & 0.00 & 0.00 & 0.00 \\
\hline
\end{tabular}

Notes: ${ }^{a}$ Model 1 represents the bivariate Pearson correlation coefficients ( $r$ ), Model 2 presents the partial Pearson correlation coefficients ( $r$ ) (controlling for the informant quality variable - INQ), and Model 3 contains the differences between the values outlined in Model 1 and Model 2. Please note that the significances of the Pearson correlation coefficients were not recorded as part of the marker variable technique. 